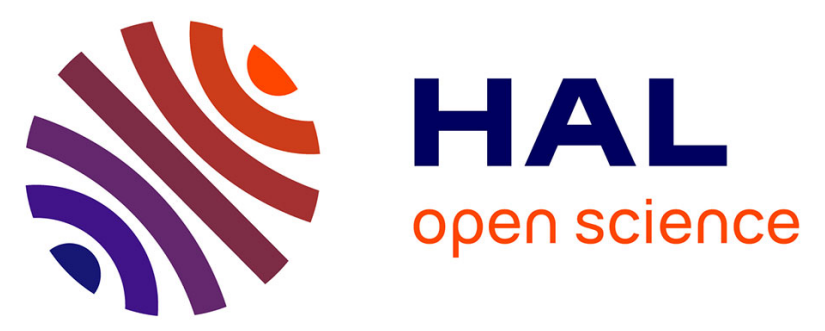

\title{
'Clickable' cyclopentadienyl iron carbonyl complexes for bioorthogonal conjugation of mid-infrared labels to a model protein and PAMAM dendrimer
}

Nathalie Fischer-Durand, Daria Lizinska, Vincent Guérineau, Bogna Rudolf, Michèle Salmain

\section{To cite this version:}

Nathalie Fischer-Durand, Daria Lizinska, Vincent Guérineau, Bogna Rudolf, Michèle Salmain. 'Clickable' cyclopentadienyl iron carbonyl complexes for bioorthogonal conjugation of mid-infrared labels to a model protein and PAMAM dendrimer. Applied Organometallic Chemistry, 2019, 33 (4), pp.e4798. 10.1002/aoc.4798 . hal-02089704

\section{HAL Id: hal-02089704 https://hal.sorbonne-universite.fr/hal-02089704}

Submitted on 4 Apr 2019

HAL is a multi-disciplinary open access archive for the deposit and dissemination of scientific research documents, whether they are published or not. The documents may come from teaching and research institutions in France or abroad, or from public or private research centers.
L'archive ouverte pluridisciplinaire HAL, est destinée au dépôt et à la diffusion de documents scientifiques de niveau recherche, publiés ou non, émanant des établissements d'enseignement et de recherche français ou étrangers, des laboratoires publics ou privés. 


\title{
"Clickable" cyclopentadienyl iron carbonyl complexes for bioorthogonal conjugation of mid infrared labels to a model protein and PAMAM
}

\section{dendrimer}

Nathalie Fischer-Durand, ${ }^{1}$ Daria Lizinska, ${ }^{2}$ Vincent Guérineau, ${ }^{3}$ Bogna Rudolf, ${ }^{2}$ Michèle Salmain ${ }^{1 *}$

${ }^{1}$ Sorbonne Université, CNRS, Institut Parisien de Chimie Moléculaire (IPCM), 4 place Jussieu 75005 Paris, France

${ }^{2}$ University of Lodz, Department of Organic Chemistry, Tamka 12, 91-403 Lodz, Poland

${ }^{3}$ Institut de Chimie des Substances Naturelles, CNRS UPR2301, Université Paris-Sud, Université Paris-Saclay, Avenue de la Terrasse, 91198 Gif-sur-Yvette Cedex, France.

\section{Dedicated to Professor Janusz Zakrzewski on occasion of his seventieth birthday}

\section{SHORT TITLE}

Bioconjugation of metallocarbonyl infrared labels by click chemistry

\section{Keywords}

CuAAC; SPAAC; metallocarbonyl complex; IR spectroscopy; bioconjugation

\begin{abstract}
Owing to the intrinsic limitations of the conventional bioconjugation methods involving proteins native nucleophilic functions, we sought to develop alternative approaches to introduce metallocarbonyl infrared labels onto proteins on the basis of the [3+2] dipolar azide alkyne cycloaddition (AAC). To this end, two cyclopentadienyl iron dicarbonyl (Fp) complexes carrying a terminal or a strained alkyne handle were synthesized. Their reactivity was examined towards a model protein and poly(amidoamine) (PAMAM) dendrimer, both carrying azido groups. While the copper(I)-catalysed azide-alkyne cycloaddition (CuAAC) proceeded smoothly with the terminal alkyne metallocarbonyl derivative, labelling by strainpromoted azide-alkyne cycloaddition (SPAAC) was less successful in terms of final coupling ratios. Infrared spectral characterization of the bioconjugates showed the presence of two bands in the $2000 \mathrm{~cm}^{-1}$ region, owing to the stretching vibration modes of the carbonyl ligands of the Fp entities.
\end{abstract}




\section{Introduction}

Most of the conventional protein bioconjugation methods rely on the nucleophilicity of the $\varepsilon$ amino group borne by their lysine residues. ${ }^{[1,2]}$ However, they always afford a complex mixture of bioconjugates owing to the high abundance of lysine residues in proteins. An alternative to lysine chemical modification is the modification of the other highly nucleophilic function of proteins, namely the $\beta$-sulfhydryl group of cysteines. Although, site-specific bioconjugation can sometimes be reached owing to the low abundance of free cysteines in proteins, this approach can still be problematic because of the instability of the bond created between the protein and the label under certain conditions. ${ }^{[3,4]}$ In any case, none of these strategies are applicable to the labelling of a single biomolecule in a complex medium without interference of the other components or when a specific part of the biomolecule to be labelled is targeted.

To circumvent these issues, new bioconjugation methods relying on non naturally occurring functional groups have been introduced. ${ }^{[5-11]}$ They are collectively named bioorthogonal or "click" reactions. Among these reactions, the [3+2] dipolar cycloaddition between azides and alkynes affording 1,4-disubstituted 1,2,3-triazoles has attracted a lot of interest in its coppercatalyzed (CuAAC) or copper-free strained alkyne versions (SPAAC), ${ }^{[12-18]}$ initiated by the concomitant works of Meldal and Sharpless groups ${ }^{[19,20]}$ and followed by the strained alkyne version initiated by Bertozzi group. ${ }^{[21]}$ Proteins to be labelled by AAC are first to be equipped with an azide or an alkyne handle, either chemically or metabolically, ${ }^{[18]}$ before the label carrying the partner orthogonal group is conjugated.

Metal carbonyl complexes show specific and intense absorption bands in the mid-infrared spectral range (2200-1800 $\left.\mathrm{cm}^{-1}\right)$ owing the carbonyl ligands, where few others vibrators absorb. These features make them detectable at very low concentration by IR spectroscopic techniques. Metal carbonyl complexes have been applied to the study of biomolecule/protein interactions in biological systems, ${ }^{[22]}$, as non-isotopic labels for immunoassays ${ }^{[23]}$ and for bioimaging ${ }^{[24-26]}$. Several metal carbonyl entities $\left(\mathrm{Mn}(\mathrm{CO})_{3}, \operatorname{Re}(\mathrm{CO})_{3}, \mathrm{Ru}(\mathrm{CO})_{\mathrm{x}}\right)$ have been attached to proteins using a dative anchoring approach via coordination of imidazole. ${ }^{[27]}$ When the protein was lysozyme, site-specific binding occurred involving its single histidine residue. ${ }^{[28,29]}$ There have been few reports dealing with the labelling of peptides / proteins by metal carbonyl complexes via CuAAC or SPAAC so far. For instance, site-specific 
conjugation of the infrared label $\left[\left(\eta^{5}-\mathrm{C}_{5} \mathrm{H}_{4} \mathrm{C} \equiv \mathrm{CH}\right) \operatorname{Re}(\mathrm{CO})_{3}\right]$ to the azido homoalanine modified C-terminal domain of the ribosomal protein L9 was achieved via $\mathrm{CuAAC}$ in the presence of $\mathrm{CuSO}_{4}$, ascorbate and THPTA. The position of the stretching vibration modes of the $\mathrm{CO}$ ligands and the lifetimes were then used to probe protein solvation and electrostatics. ${ }^{[30]}$ Alkyne-containing peptide nucleic acids (PNA) were labelled with azidomodified dipicolylamine/amide rhenium tricarbonyl or 99m-technetium tricarbonyl moieties for radiotherapeutic purposes. ${ }^{[31,32]}$ Other representative examples dealt with the labelling of peptides / proteins with bipyridyl rhenium tricarbonyl luminescent labels, ${ }^{[33-37]}$ and cymantrene entity as IR probe. ${ }^{[38]}$

We have previously prepared complex $\mathbf{2}$ carrying a terminal alkyne group (Figure 1) by azaMichael addition between propargylamine and $\left[\left(\eta^{5}\right.\right.$-cyclopentadienyl $) \mathrm{Fe}(\mathrm{CO})_{2}\left(\eta^{1}-\mathrm{N}\right.$ maleimidato)] 1. This complex was shown to undergo [3+2] cycloaddition with model aryl azides using $\mathrm{CuCl} / \mathrm{Cu}^{0}$ as catalyst in ${ }^{\mathrm{t}} \mathrm{BuOH} / \mathrm{H}_{2} \mathrm{O}$ mixture affording the corresponding 1,2,3triazoles in very good yield. ${ }^{[39]}$ In this paper, we report the synthesis of a strained alkyne derivative $\mathbf{3}$ along with conjugation of $\mathbf{2}$ and $\mathbf{3}$ to the model protein bovine serum albumin (BSA) and poly(amidoamine) dendrimer generation 4 (PAMAM-G4). Bioconjugates were characterized by a range of spectroscopic techniques. It appeared that the presence of a strained alkyne handle was poorly compatible with the $\mathrm{CpFe}(\mathrm{CO})_{2}$ (further called Fp) entity in compound 3, resulting in low coupling ratios by SPAAC. Conversely, we found that the experimental conditions required for $\mathrm{CuAAC}$ were fully compatible with the Fp moiety, leading to good coupling ratios.

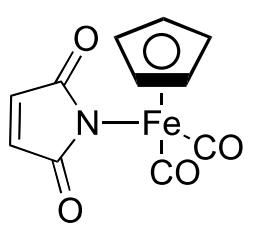

1

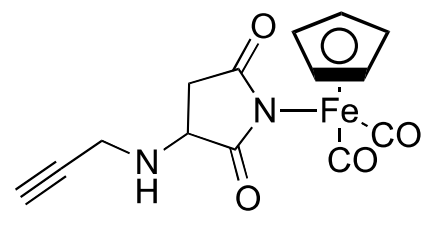

2

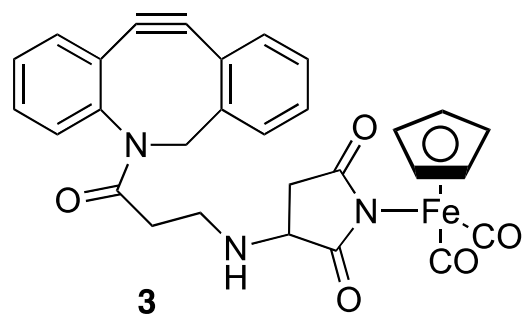

FIGURE 1 Structures of metallocarbonyl complexes discussed here.

\section{Experimental}

\subsection{Reagents and Materials}

Amine-terminated PAMAM-G4 dendrimer ethylenediamine core, 4-fluoro-3-nitrobenzoic acid, $N, N$-diisopropylethylamine (DIPEA), 1,1,1-trifluoroethanol (TFE), O-(2-aminoethyl)- 
O'-(2-azidoethyl) heptaethylene glycol and $N, N, N^{\prime}, N^{\prime}$-tetramethyl- $O-(N$ -

succinimidyl)uronium tetrafluoroborate (TSTU) were purchased from Sigma-Aldrich Co. $\mathrm{MeO}-\mathrm{PEG}-\mathrm{OH}(750)$ and azadibenzocyclooctyne-amine (ADIBO-NH $\mathrm{N}_{2}$ ) were purchased from Alfa Aesar. Compound 1 was synthesized as described previously. ${ }^{[40]}$ 4-butylamino-3nitrobenzoic acid was synthesized as described previously. ${ }^{[41]}$ Dialysis was performed with Spectra/Por 1 membranes with a molecular weight cutoff of 6-8000 Da (Spectrum Laboratories, Inc.). Protein solutions were concentrated using Amicon Ultra ${ }^{\circledR}$ Centrifugal Filter Devices (Millipore). Nitrocellulose membranes (pore size, $0.45 \mu \mathrm{m}$ ) were purchased from Bio-Rad and GE Healthcare Life Sciences. Flash chromatography was performed on silica gel 60 (Merck, 40-63 $\mu \mathrm{m}$ ). Sephadex LH-20 was purchased from GE Life sciences. UV/Vis spectra were recorded on a Cary 50 spectrophotometer (Varian) and analyzed with Cary WinUV Bio 3.0 software. NMR spectra were recorded on BRUKER Avance 300 and BRUKER Avance 400 spectrometers. Electrospray ionization (ESI) mass spectra were obtained on a API-3000 (Applied Biosystems, PE Sciex) coupled to an LC Agilent 1100 series. HR ESI-MS were obtained on a micrOTOF (BRUKER).

\subsection{Instrumentation}

\subsubsection{FT-IR spectroscopy}

FT-IR spectra were recorded on a benchtop Tensor 27 IR spectrometer (Bruker) equipped with a DTGS detector, and a $6 \mathrm{~mm}$-diameter membrane holder perpendicularly positioned with respect to the IR beam. FT-IR data were recorded and manipulated on a Windowsoperating PC using the OPUS 6.5 software. Routinely, 44 scans were coadded in 40 seconds and the resulting interferogram was apodized using a Blackman-Harris 3-Term function and then Fourier-transformed to yield a $4 \mathrm{~cm}^{-1}$ resolution spectrum.

The calibration curve used for quantification of Fp in conjugates was established as follows: standard solutions of Fp-maleimide in the range 50-660 nmol/mL in $10 \mathrm{mM} \mathrm{NaPB} \mathrm{pH} 7.2$ were spotted $(4 \mu \mathrm{L})$ onto punched nitrocellulose membranes (diameter $=6 \mathrm{~mm}$ ). A blank was made by spotting $4 \mu \mathrm{L}$ of NaPB. Membranes were dried for at least $2 \mathrm{~h}$ at room temperature in the dark before IR recording in the range $1800-2200 \mathrm{~cm}^{-1}$. The calibration curve was constructed by plotting the absorbance at $2052 \mathrm{~cm}^{-1}$ versus the concentration of the standard solutions of Fp-maleimide. This experiment was repeated several times and gave reproducible standard straight lines.

Quantification of Fp in protein or PAMAM conjugates solutions was carried out as follows: protein conjugate was appropriately diluted in $10 \mathrm{mM}$ NaPB pH 7.2 while PAMAM 
conjugate was first dissolved in $2 \mathrm{~mL} \mathrm{MeOH}$ then diluted appropriately with $10 \mathrm{mM} \mathrm{NaPB}$ $\mathrm{pH}$ 7.2. The solution ( $4 \mu \mathrm{L})$ was spotted onto a nitrocellulose membrane (in duplicate) and dried for at least $2 \mathrm{~h}$ in the dark. A blank membrane was prepared by spotting the same volume of NaPB. FT-IR spectra were then recorded between 1800 and $2200 \mathrm{~cm}^{-1}$. Absorbances at $2052 \mathrm{~cm}^{-1}$ were used to calculate the average concentration of Fp entities using the calibration curve established above.

\subsubsection{UV/Vis quantification of nitroaniline moiety}

Concentration of nitroaniline in dendrimer conjugates was measured by UV/Vis spectroscopy at $416 \mathrm{~nm}$ in methanol using a calibration curve established using known concentrations of 4butylamino-3-nitrobenzoic acid ${ }^{[41]}$ in methanol ranging from 0.0125 to $0.4 \mu \mathrm{mol} / \mathrm{mL}$ (y= $4.7564 x+0.0428$ ). Typically, dendrimer was dissolved in $2 \mathrm{~mL}$ methanol then diluted to fit the concentration range of the calibration curve.

To measure the concentration of nitroaniline moiety when nitroaniline and Fp were both conjugated to the dendrimer, a calibration curve at $416 \mathrm{~nm}$ was also established using known concentrations of complex 1 in methanol ranging from 0.2 to $3.2 \mu \mathrm{mol} / \mathrm{mL}(\mathrm{y}=0.4838 \mathrm{x}+$ 0.0055). Absorbance of Fp entity was subtracted from total absorbance knowing the concentration of Fp entity determined by IR quantification $(\S 2.2 .1)$.

\subsubsection{MALDI-TOF Mass Spectrometry}

A Voyager DE-STR MALDI-TOF mass spectrometer (Perseptive Biosystems, Framingham, MA, USA), equipped with a 337-nm pulsed nitrogen laser $(20 \mathrm{~Hz})$ and an Acqiris $\AA^{\circledR} \mathrm{GHz}$ digitizer board, was used for all experiments.

Mass spectra were obtained in linear positive ion mode with the following settings: accelerating voltage $25 \mathrm{kV}$, grid voltage $94 \%$ of accelerating voltage, extraction delay time of 700 ns. The laser intensity was set just above the ion generation threshold to obtain peaks with the highest possible signal-to-noise $(\mathrm{S} / \mathrm{N})$ ratio without significant peak broadening.

The mass spectrometer was externally calibrated using the protonated molecule of cytochrome $\mathrm{C}\left([\mathrm{M}+\mathrm{H}]^{+}, m / z\right.$ 12361.12), horse heart myoglobin $\left([\mathrm{M}+\mathrm{H}]^{+}, m / z\right.$ 16952.50), trypsinogen $\left([\mathrm{M}+\mathrm{H}]^{+}, m / z\right.$ 23982.00) and enolase $\left([\mathrm{M}+\mathrm{H}]^{+}, m / z\right.$ 46671.96).

All data were processed using the Data Explorer software package (Applied Biosystems). 2,4,6-trihydroxyacetophenone (THAP) was used as the matrix. The THAP matrix solution was prepared by dissolving $10 \mathrm{mg}$ in $500 \mu \mathrm{L}$ of water and $500 \mu \mathrm{L}$ of methanol. $1 \mu \mathrm{L}$ of the 
analyte $([G 4]=98 \mu M)$ and $9 \mu \mathrm{L}$ of the matrix solution were mixed together and $1 \mu \mathrm{L}$ of the resulting solution was spotted on the MALDI plate and air dried ("Dried Droplet" method). PAMAM-G4 has a theoretical mass of 14215 but PAMAM dendrimers are known to have branching defects (missing arms and intermolecular loops) ${ }^{[42]}$ resulting in slight mass deviation from batch to batch (see spectra in SI).

\subsection{Syntheses}

\subsubsection{Precautions for handling dendrimers}

The functionalized dendrimers described in this paper must be kept in solution at all times otherwise it is not possible to dissolve them again. Moreover, it has been shown that degradation occurs during storage, freeze-thaw and concentration of terminal amino or hydroxy PAMAM dendrimers explaining why the commercial product is always sold as a $10 \% \mathrm{w} / \mathrm{w}$ solution. ${ }^{[43]}$ Consequently, compounds cannot be thoroughly dried before NMR recording. Accordingly, to eliminate traces of $\mathrm{MeOH}$, each sample is evaporated to dryness no more than $1 \mathrm{~min}$, then dissolved two times with $0.8 \mathrm{~mL} \mathrm{MeOH}-d_{4}$ and evaporated. As functionalized dendrimers are not unimolecular, their characterization by NMR represent the average value of their polymeric distribution.

\subsubsection{Azido-derivatized $B S A\left(B S A-N_{3}\right)$}

$\mathrm{K}_{2} \mathrm{CO}_{3}\left(8 \mathrm{mg} / \mathrm{mL}\right.$ in $\left.\mathrm{H}_{2} \mathrm{O}, 1 \mathrm{~mL}\right), \mathrm{CuSO}_{4}, 5 \mathrm{H}_{2} \mathrm{O}\left(4 \mathrm{mg} / \mathrm{mL}\right.$ in $\left.\mathrm{H}_{2} \mathrm{O}, 250 \mu \mathrm{L}\right)$, and imidazole-1-

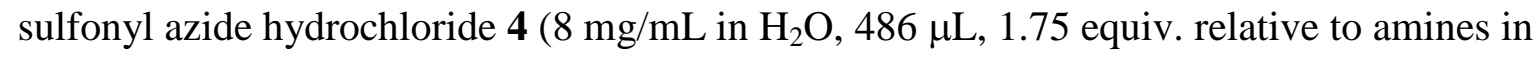
BSA $),{ }^{[44]}$ were added to a solution of BSA $\left(20 \mathrm{mg}, \mathrm{q}\left(\mathrm{NH}_{2}\right)=10.6 \mu \mathrm{mol}\right)$ in $\mathrm{H}_{2} \mathrm{O}(2 \mathrm{~mL})$ and the reaction mixture was gently shaken at room temperature overnight. The mixture was purified by dialysis against $40 \mathrm{mM} \mathrm{NaPB} \mathrm{pH} 7.5$ for $48 \mathrm{~h}$ at $4{ }^{\circ} \mathrm{C}$ and concentrated on an Amicon Ultra ${ }^{\circledR}$ Centrifugal Filter Device $(30 \mathrm{kDa})$. The concentrated solution was diluted in $40 \mathrm{mM}$ NaPB pH 7.5 and concentrated again (3 times). Protein concentration was measured at $280 \mathrm{~nm}\left(\varepsilon(\mathrm{BSA})=0.677 \mathrm{~mL} \cdot \mathrm{mg}^{-1} \cdot \mathrm{cm}^{-1}\right)$. IR spectrum was recorded on nitrocellulose membrane: a diluted solution of $\mathrm{BSA}^{-\mathrm{N}_{3}}(4 \mu \mathrm{L})$ was deposited on membrane and left to dry at least for $2 \mathrm{~h}$. A blank was made by spotting the same volume of NaPB (Figure 3-A). A TNBS assay was performed to estimate the degree of protein modification according to an established procedure ${ }^{[45]}$ and showed that 68 to $86 \%$ of the accessible amine groups were converted to azide groups.

\subsubsection{CuAAC of BSA-N 3 with complex 2.}


Due to the acute oxygen sensitivity of sulfonated bathophenanthroline ligand $\mathbf{5}$, water, and sodium phosphate buffer were degassed before reaction and a slight bubbling of argon was maintained during incubation. A pre-mixed solution consisting of $\mathrm{CuSO}_{4} .5 \mathrm{H}_{2} \mathrm{O}(200 \mu \mathrm{L}, 14$ $\mathrm{mM}$ in $\left.\mathrm{H}_{2} \mathrm{O}\right)$, ligand $5\left(150 \mu \mathrm{L}, 37 \mathrm{mM}\right.$ in $\left.\mathrm{H}_{2} \mathrm{O}\right)$ and sodium ascorbate $(150 \mu \mathrm{L}, 19 \mathrm{mM}$ in $\left.\mathrm{H}_{2} \mathrm{O}\right)$ was added to the solution of BSA-( $\left.\mathrm{N}_{3}\right)_{30}(91 \mathrm{nmol})$ and alkyne complex $2(1.81 \mu \mathrm{mol}$, 20 molar equiv) in $40 \mathrm{mM} \mathrm{NaPB}$ pH $7.5(1.6 \mathrm{~mL})$. After $18 \mathrm{~h}$ at room temperature in the dark, the solution was dialyzed against $40 \mathrm{mM} \mathrm{NaPB} \mathrm{pH} 7.5$ at $4^{\circ} \mathrm{C}$ for 4 days (daily change of buffer) then concentrated with Amicon Ultra® Centrifugal Filter Device (30 kDa). The concentrated solution was redissolved in $40 \mathrm{mM} \mathrm{NaPB} \mathrm{pH} 7.5$ and concentrated again (3 times). IR spectrum was recorded on nitrocellulose membrane after dilution in PBS pH 7.4 to quantify the Fp entity $(\$ 4.2 .1,1.86 \mu \mathrm{mol} / \mathrm{mL})$ and the protein concentration was determined by the Lowry procedure ${ }^{[46]}(0.23 \mu \mathrm{mol} / \mathrm{mL})$. Fp-to-protein ratio: 8 .

\subsubsection{Azido-derivatized PAMAM-G4 6}

$\mathrm{K}_{2} \mathrm{CO}_{3}(73.5 \mathrm{mg}, 0.532 \mathrm{mmol}), \mathrm{CuSO}_{4}, 5 \mathrm{H}_{2} \mathrm{O}(0.74 \mathrm{mg}, 2.96 \mu \mathrm{mol})$, and imidazole-1-sulfonyl azide hydrochloride $4(64.6 \mathrm{mg}, 0.308 \mathrm{mmol})$ were added to a solution of PAMAM-G4 (1.2 $\mathrm{mL}, 6.86 \mu \mathrm{mol})$ in methanol $(1.8 \mathrm{~mL})$. The reaction mixture was stirred at room temperature for $24 \mathrm{~h}$ and the dendrimer was purified by dialysis in $\mathrm{H}_{2} \mathrm{O}$ for 5 days (daily change of $\mathrm{H}_{2} \mathrm{O}$ ). The solution was freeze-dried to afford PAMAM G4-N $3(52 \mathrm{mg})$. The residue was dissolved in $2 \mathrm{~mL} \mathrm{MeOH}$ and stored at $4^{\circ} \mathrm{C}$ in $\mathrm{MeOH}$. To perform IR on nitrocellulose membrane, the methanol solution ( $4 \mu \mathrm{L}$ ) was left to dry, the residue dissolved in $4 \mu \mathrm{L} \mathrm{H}_{2} \mathrm{O}$ and deposited on membrane ( $\mathrm{MeOH}$ is not recommended with nitrocellulose membrane). MALDI-TOF MS $\mathrm{m} / \mathrm{z} 14600\left(\mathrm{G} 4-\mathrm{N}_{3}\right), 13869$ (commercial G4), $\Delta \mathrm{m}=731,28$ azides per dendrimer. Yield = $52 \%$.

\subsubsection{Synthesis of carbonate 8}

Synthesis of 8 was carried out according to Kojima et al. ${ }^{[47]}$ Briefly, MeO-PEG-OH(750) (0.5 g, $0.67 \mathrm{mmol}$ ) was dissolved in anhydrous THF (35 mL). 4-nitrophenyl chloroformate $(0.27$ $\mathrm{g}, 1.34 \mathrm{mmol})$ and triethylamine $(185 \mu \mathrm{L}, 1.34 \mathrm{mmol})$ were added. The reaction mixture was stirred at room temperature for $36 \mathrm{~h}$. The precipitate was removed by filtration and THF was evaporated from the solution. The crude was dissolved in $\mathrm{MeOH}$ and purified in two batches by chromatography on Sephadex $\mathrm{LH}-20$ column $(30 \times 1 \mathrm{~cm})$ in $\mathrm{MeOH}$ to yield a pale yellow oil (0.46 g, 76\%). ${ }^{1} \mathrm{H}$ NMR (300 MHz, $\left.\mathrm{CDCl}_{3}\right)$ O $1.34\left(\mathrm{~s}, \mathrm{OCH}_{3}\right), 3.6-3.8\left(\mathrm{~m}, \mathrm{CH}_{2} \mathrm{CH}_{2} \mathrm{O}\right), 4.38$ $\left(\mathrm{m}, \mathrm{CH}_{2} \mathrm{OCO}_{2} \mathrm{Ar}\right), 7.34\left(\mathrm{~d}, J=9 \mathrm{~Hz}, 2 \mathrm{H}_{\mathrm{Ar}}\right), 8.22\left(\mathrm{~d}, J=9 \mathrm{~Hz}, 2 \mathrm{H}_{\mathrm{Ar}}\right) .{ }^{13} \mathrm{C} \mathrm{NMR}(75.5 \mathrm{MHz}$, 
$\mathrm{CDCl}_{3}$ ) D 59.0, 61.6 (unactivated MeOPEG-OH); 68.3, 68.6, 70.3, 70.5, 70.6, 70.6, 70.6, 70.7, 71.9, 72.5 (unactivated MeOPEG-OH), 121.8, 125.3, 145.3, 152.4, 155.5. ESI-MS m/z 787.8 $(n=12), 831.7(n=13), 875.9(n=14), 919.6(n=15), 963.9(n=16), 1007.9(n=17), 1051.8$ ( $\mathrm{n}=18), 1096.0(\mathrm{n}=19)\left[\mathrm{M}+\mathrm{NH}_{4}\right]^{+}$with $\mathrm{M}=\mathrm{MeO}\left(\mathrm{CH}_{2} \mathrm{CH}_{2} \mathrm{O}\right)_{n} \mathrm{CH}_{2} \mathrm{CH}_{2} \mathrm{OCOOAr}$, the distribution was gaussian.

\subsubsection{Synthesis of dendrimer $9\left(P A M A M-G 4\left(N_{3}\right)_{28}(P E G)_{12}\right)$}

PAMAM-G4 $\left(\mathrm{N}_{3}\right)_{28}(2 \mu \mathrm{mol})$ and carbonate 8 (46 mg, $36 \mu$ mol taking into account that only $70 \%$ of 8 is carbonate) were reacted in DMSO $(1.5 \mathrm{~mL})$ for 4 days. The solution was dialyzed against $\mathrm{H}_{2} \mathrm{O}$ for 8 days (daily change of $\mathrm{H}_{2} \mathrm{O}$ ) and freeze-dried to afford PAMAM$\mathrm{G} 4\left(\mathrm{~N}_{3}\right)_{28}(\mathrm{PEG})_{12} 9(36.7 \mathrm{mg})$. The compound was stored at $4^{\circ} \mathrm{C}$ in $\mathrm{MeOH}$. MALDI-TOF MS: m/z $23900(9), 14600\left(\mathrm{G} 4-\mathrm{N}_{3}\right), \Delta \mathrm{m}=9300$ (12 PEG attached). Yield = 77\%.

\subsubsection{Synthesis of dendrimer 10: CuAAC of PAMAM-G4(N $\left.N_{3}\right)_{28}(P E G)_{12}$ with complex 2.}

In order to remove oxygen to maintain copper in the active +1 oxidation state, argon was bubbled in $t-\mathrm{BuOH} / \mathrm{H}_{2} \mathrm{O}(1: 1)$ and the cycloaddition was carried out under argon. To a solution of PAMAM-G4(N $)_{28}(\mathrm{PEG})_{12}(0.8 \mu \mathrm{mol})$ and $2(8.45 \mathrm{mg}, 25.8 \mu \mathrm{mol})$ in $t$ $\mathrm{BuOH} / \mathrm{H}_{2} \mathrm{O}(4 \mathrm{~mL}, 1: 1), \mathrm{Cu}^{0}(25 \mathrm{mg}$ as flat wire, rinsed successively with $10 \% \mathrm{HCl}$ for 2 min, $\mathrm{H}_{2} \mathrm{O}, 16 \% \mathrm{HNO}_{3}$ for $2 \mathrm{~min}$ and $\left.\mathrm{H}_{2} \mathrm{O}\right)$ and $\mathrm{CuCl}(1.6 \mathrm{mg})$ were added. The reaction mixture was stirred at room temperature in the dark for 3 days and the solution was dialyzed in $\mathrm{MeOH} / \mathrm{H}_{2} \mathrm{O}$ (1:1) for 2 days then in $\mathrm{MeOH} / \mathrm{H}_{2} \mathrm{O}$ (1:1) containing $3 \mathrm{mM}$ EDTA for 6 days to remove copper ions by chelation, then in $\mathrm{MeOH} / \mathrm{H}_{2} \mathrm{O}$ (1:1) for 2 days to remove EDTA and finally in $\mathrm{MeOH}$ for 3 days (with daily change of each solution) to afford PAMAM$\mathrm{G} 4\left(\mathrm{~N}_{3}\right)_{28}(\mathrm{PEG})_{12}(\mathrm{Fp})_{7} \mathbf{1 0}$. The compound was stored in $\mathrm{MeOH}$ at $4^{\circ} \mathrm{C}$ in the dark. IR spectrum was recorded on nitrocellulose membrane after dilution in PBS pH 7.4 (figure 4-D). MALDI-TOF MS: m/z 24950 (10), 23900 (9), $\Delta \mathrm{m}=1050$ (7 Fp attached).

2.3.8. Synthesis of 4-[O-(2-aminoethyl)-O'-(2-azidoethyl)-heptaethoxy]-3-nitro-benzoic acid 11.

DIPEA (019 mL, $1.08 \mathrm{mmol})$ and O-(2-aminoethyl)-O'-(2-azidoethyl)-heptaethylene glycol $(0.25 \mathrm{~g}, 0.57 \mathrm{mmol})$ were added to a solution of 4-fluoro-3-nitro-benzoic acid $(0.1 \mathrm{~g}, 0.54$ mmol) in THF $(1.5 \mathrm{~mL})$ at $28^{\circ} \mathrm{C}$ for 1 week. The reaction mixture was diluted in EtOAc and EtOAc. $\mathrm{HCl}$ was added. Chromatography on silica gel was directly performed after partial evaporation of EtOAc (EtOAc/MeOH/AcOH, 96:4:0.7) to afford compound 11 as a yellow oil (0.26 g, 80\%). ${ }^{1} \mathrm{H}$ NMR (300 MHz, $\mathrm{CDCl}_{3}$ ) D 3.34 (t, J=5.0 Hz, $\mathrm{CH}_{2} \mathrm{~N}_{3}$ ), 3.52 (q, J=5.0 Hz, 
$\mathrm{CH}_{2} \mathrm{NHAr}$ ), $3.62\left(\mathrm{~m}, \mathrm{CH}_{2} \mathrm{CH}_{2} \mathrm{O}\right), 3.78$ (t, $\left.J=5.2 \mathrm{~Hz}, 2 \mathrm{H}\right), 6.84$ (d, J=9.2 Hz, $\mathrm{H}_{\mathrm{Ar}}$ ), 8.0 (bd, $\left.J=9.0 \mathrm{~Hz}, \mathrm{H}_{\mathrm{Ar}}\right), 8.54(\mathrm{t}, J=4.9 \mathrm{~Hz}, \mathrm{NH}), 8.82\left(\mathrm{~d}, J=1.7 \mathrm{~Hz}, \mathrm{H}_{\mathrm{Ar}}\right), 10.81\left(\mathrm{CO}_{2} \mathrm{H}\right) .{ }^{13} \mathrm{C} \mathrm{NMR}$ (75.5 MHz, $\left.\mathrm{CDCl}_{3}\right)$ D 42.9, 50.6, 68.7, 70.0, 70.5, 70.6, 113.6, 116.8, 130.0, 131.3, 136.5, 147.8, 169.1. UV/Vis $\lambda_{\max }(\mathrm{MeOH}) 416 \mathrm{~nm}$. HR ESI-MS $m / z$ calcd for $\mathrm{C}_{25} \mathrm{H}_{41} \mathrm{~N}_{5} \mathrm{O}_{12} \mathrm{Na}(\mathrm{M}+$ $\mathrm{Na})^{+}$626.2644, found 626.2641. NMR spectra and HPLC are available in SI.

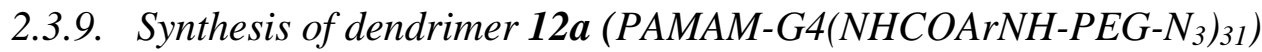

PAMAM-G4 was first transferred into TFE by MeOH evaporation of the commercial sample under vacuum, addition of TFE $(1 \mathrm{~mL})$ and evaporation (procedure repeated 3 times to remove traces of methanol).

To a solution of 11 (34 mg, $56.4 \mu \mathrm{mol})$ in DMF (700 $\mu \mathrm{L})$ were added TSTU (20.4 mg, 67.7 $\mu \mathrm{mol})$ and DIPEA $(22.6 \mu \mathrm{L}, 130 \mu \mathrm{mol})$. The solution was stirred at room temperature for 45 min, cooled in an ice bath and PAMAM-G4 $(1.144 \mu \mathrm{mol})$ in TFE $(500 \mu \mathrm{L})$ was added. The solution was stirred at room temperature for 3 days then dialyzed in methanol (daily change) at room temperature until excess 11 was removed (UV monitoring of the external solution, 10 days). ${ }^{1} \mathrm{H}$ NMR (300 MHz, $\left.\mathrm{CD}_{3} \mathrm{OD}\right) \partial 2.36$ (br, $\left.248 \mathrm{H}\right), 2.56$ (br, $\left.144 \mathrm{H}\right), 2.77$ (br, $240 \mathrm{H}$ ), 3.25-3.50 (m + $\left.\mathrm{CD}_{3} \mathrm{OD}\right), 3.5-3.66\left(\mathrm{~m}, \mathrm{CH}_{2} \mathrm{CH}_{2} \mathrm{O}\right), 3.77$ (br, $\left.\mathrm{CH}_{2} \mathrm{NHAr}\right), 7.00$ (br, $31 \mathrm{H}_{\mathrm{Ar}}$ ), $7.90\left(\mathrm{br}, 31 \mathrm{H}_{\mathrm{Ar}}\right), 8.57\left(\mathrm{br}, 31 \mathrm{H}_{\mathrm{Ar}}\right.$ ). [nitroaniline]= $15 \mu \mathrm{mol} / \mathrm{mL}$ (quantification by UV/Vis at $416 \mathrm{~nm}$, dendrimer in $2 \mathrm{~mL} \mathrm{MeOH}$ ), calculated [G4] $=0.488 \mu \mathrm{mol} / \mathrm{mL}$ (85\% yield); The ninhydrine test was carried out according to the procedure of Luo et al. with minor modifications. ${ }^{[48]}$ A calibration curve was constructed for commercial PAMAM-G4 $(3 \mu \mathrm{L} / \mathrm{mL}$ ethanol, [G4] = $17.16 \mathrm{nmol} / \mathrm{mL},\left[\mathrm{NH}_{2}\right]=1098 \mathrm{nmol} / \mathrm{mL}$ ). Volumes between 0 and $250 \mu \mathrm{L}$ were diluted with ethanol to a total volume of $250 \mu \mathrm{L}$ and combined with $750 \mu \mathrm{L}$ of ninhydrin ( $0.4 \mathrm{wt} \%$ in ethanol). Solutions were heated for $5 \mathrm{~min}$ at $75^{\circ} \mathrm{C}$, cooled, diluted with $1 \mathrm{~mL}$ ethanol and absorbances were measured at $590 \mathrm{~nm}$. Dendrimer 12a was diluted in ethanol to reach the concentration of the highest standard and the reaction with ninhydrin was performed in the same time. Absorbances were used to determine the percentage of reactive surface amines, relative to commercial PAMAM-G4.

\subsubsection{Synthesis of dendrimer 13: CuAAC of PAMAM-G4(NHCOArNH-PEG-N $\left.\mathrm{N}_{3}\right)_{31}$ with complex 2.}

$\mathrm{CuAAC}$ was carried out as described for the synthesis of dendrimer 10. Argon was bubbled in $t$ - $\mathrm{BuOH} / \mathrm{H}_{2} \mathrm{O}(1: 1)$. To a solution of dendrimer $\mathbf{1 2 a}(0.97 \mu \mathrm{mol}, 30 \mu \mathrm{mol}$ in nitroaniline $)$ and complex $2(9.8 \mathrm{mg}, 30 \mu \mathrm{mol})$ in $t-\mathrm{BuOH} / \mathrm{H}_{2} \mathrm{O}(2 \mathrm{~mL}, 1: 1), \mathrm{Cu}^{0}(28 \mathrm{mg}$ as flat wire, rinsed 
successively with $10 \% \mathrm{HCl}$ for 2 min, $\mathrm{H}_{2} \mathrm{O}, 16 \% \mathrm{HNO}_{3}$ for 2 min and $\left.\mathrm{H}_{2} \mathrm{O}\right)$ and $\mathrm{CuCl}(1.4$ $\mathrm{mg}$ ) were added. The reaction mixture was stirred at room temperature in the dark for 3 days with gentle argon bubbling. The solution was then dialyzed in $\mathrm{MeOH} / \mathrm{H}_{2} \mathrm{O}$ (1:1) for $24 \mathrm{~h}$ then in $\mathrm{MeOH} / \mathrm{H}_{2} \mathrm{O}$ (1:1) containing $3 \mathrm{mM}$ EDTA for 5 days to remove copper ions by chelation, then in $\mathrm{MeOH} / \mathrm{H}_{2} \mathrm{O}$ (1:1) for 5 days to remove EDTA and finally in $\mathrm{MeOH} / \mathrm{H}_{2} \mathrm{O}$ (2:1) for 2 days (with daily change of each solution) to afford dendrimer 13 that turned out to be not fully soluble in methanol and required a little amount of $\mathrm{H}_{2} \mathrm{O}$. Dendrimer $\mathbf{1 3}$ was stored in $\mathrm{MeOH} / \mathrm{H}_{2} \mathrm{O}$ at $4{ }^{\circ} \mathrm{C}$ in the dark. IR spectrum was recorded on nitrocellulose membrane after dilution in PBS pH 7.4 to assay the quantity of Fp in the sample $(20.2 \mu \mathrm{mol})$. Nitroaniline quantity was measured by absorbance at $416 \mathrm{~nm}$ after subtraction of Fp absorbance from total absorbance $(25.3 \mu \mathrm{mol}, \S 2.2 .2)$. The ratio between these figures showed that $80 \%$ of azide groups were converted to triazole derivatives. MALDI-TOF MS m/z 34930 (13), 14090 (PAMAM-G4), $\Delta \mathrm{m}=20$ 840. In light of the nitroaniline/Fp ratio, 6 azide derivatives and 24 Fp derivatives were linked to the dendrimer.

\subsubsection{Synthesis of $\mathrm{CpFe}(\mathrm{CO})_{2}$-succinimidyl-linked aza-dibenzocyclooctyne (ADIBO-Fp complex 3$)$.}

To a solution of ADIBO-NH $(25 \mathrm{mg}, 91 \mu \mathrm{mol})$ in ethanol $(3 \mathrm{~mL})$ were added $\mathbf{1}(25 \mathrm{mg}, 91$ $\mu \mathrm{mol})$ and triethylamine $(12 \mu \mathrm{L}, 0.89 \mathrm{mmol})$. The mixture was stirred for $27 \mathrm{~h}$ at room temperature in the dark, then concentrated in vacuo and purified by column chromatography on silica gel $\left(\mathrm{CH}_{2} \mathrm{Cl}_{2} /\right.$ methanol, 95:5) to afford compound 3 as yellow oil $(39 \mathrm{mg}, 75 \%) .{ }^{1} \mathrm{H}$ NMR (300 MHz, CDCl3) D $2.03(\mathrm{~m}, 1 \mathrm{H}), 2.25\left(\mathrm{dd}, J_{l}=17.1 \mathrm{~Hz}, J_{2}=4.8 \mathrm{~Hz}, 1 \mathrm{H}\right.$ succinimide), $2.49(\mathrm{~m}, 1 \mathrm{H}), 2.61\left(\mathrm{dd}, J_{l}=17.2 \mathrm{~Hz}, J_{2}=8.2 \mathrm{~Hz}, 1 \mathrm{H}\right.$ succinimide), $2.75\left(\mathrm{~m}, \mathrm{CH}_{2}-\mathrm{NH}-\mathrm{Su}\right), 3.38$ (dd, $J_{l}=8.1 \mathrm{~Hz}, J_{2}=4.8 \mathrm{~Hz}, 1 \mathrm{H}$ succinimide), 3.68 (d, $J=13.8 \mathrm{~Hz}, 1 \mathrm{H}$ cyclooctyne), 5.02 (s, $5 \mathrm{H} \mathrm{Cp}), 5.16$ (d, $J=15.0 \mathrm{~Hz}, 1 \mathrm{H}$ cyclooctyne), 7.28-7.43 (m, $\left.7 \mathrm{H}_{\mathrm{Ar}}\right), 7.70\left(\mathrm{~d}, J=6.0 \mathrm{~Hz}, 1 \mathrm{H}_{\mathrm{Ar}}\right)$; HR ESI-MS m/z calculated for $\mathrm{C}_{29} \mathrm{H}_{23} \mathrm{FeN}_{3} \mathrm{O}_{5}$ 550.1060; found $550.1042(\mathrm{M}+\mathrm{H})$.

\subsubsection{Labelling of $B S A-N_{3}$ with 3 by SPAAC}

To a solution of ADIBO- $\mathrm{NH}_{2}(0.22 \mathrm{mg}, 0.8 \mu \mathrm{mol})$ in $\mathrm{MeOH}(0.4 \mathrm{~mL})$ was added $1(0.22 \mathrm{mg}$, $0.8 \mu \mathrm{mol})$ and $\mathrm{NEt}_{3}(2 \mu \mathrm{L})$. After stirring for $24 \mathrm{~h}$ at RT in the dark, the mixture was concentrated under vacuum and a solution of BSA- $\left(\mathrm{N}_{3}\right)_{28}$ in PBS $(2.2 \mathrm{mg}, 33.6 \mathrm{nmol}, 0.175$ $\mathrm{mL}$ ) was added. After another $24 \mathrm{~h}$ at RT in the dark, the conjugate was dialyzed in PBS for 1 day at $4{ }^{\circ} \mathrm{C}$ in the dark and concentrated by ultrafiltration to $0.7 \mathrm{~mL}$. IR spectrum was recorded on nitrocellulose membrane after dilution in $\mathrm{PBS}$ pH 7.4 to assay the concentration 
of Fp in the sample $(\S 4.2 .1,36.3 \mathrm{nmol} / \mathrm{mL})$ and the protein concentration was determined by the Lowry procedure ${ }^{[46]}(94.2 \mathrm{nmol} / \mathrm{mL})$. Fp-to-protein ratio: 0.4 .

This experiment was repeated with $3.44 \mu \mathrm{mol}$ of $\mathrm{ADIBO}-\mathrm{NH}_{2}$ and $\mathbf{1}$ followed by incubation of BSA-( $\left.\mathrm{N}_{3}\right)_{24}(86 \mathrm{nmol})$ at $30^{\circ} \mathrm{C}$. Fp $(230 \mathrm{nmol} / \mathrm{mL})$ and protein concentrations (47 $\mathrm{nmol} / \mathrm{mL}$ ) were measured by IR and the Lowry method respectively. Fp-to-protein ratio: 5 .

\subsubsection{Labelling of PAMAM-G4 $\left(N_{3}\right)_{34}$ with 3 by SPAAC}

To a solution of ADIBO- $\mathrm{NH}_{2}(0.53 \mathrm{mg}, 1.92 \mu \mathrm{mol})$ in $\mathrm{MeOH}(0.4 \mathrm{~mL})$ was added $1(0.52$ $\mathrm{mg}, 1.92 \mu \mathrm{mol})$ and $\mathrm{NEt}_{3}(1 \mu \mathrm{L})$. After stirring for $24 \mathrm{~h}$ at $\mathrm{RT}$ in the dark, a solution of PAMAM-G4 $\left(\mathrm{N}_{3}\right)_{34} \mathbf{1 2 b}$ in $\mathrm{MeOH}$ was added $(0.1 \mathrm{~mL}, 76 \mathrm{nmol})$ and $\mathrm{EtOH} / \mathrm{H}_{2} \mathrm{O}(0.2 \mathrm{~mL})$. The mixture was stirred at $25^{\circ} \mathrm{C}$ for another $24 \mathrm{~h}$ and dialyzed in $\mathrm{MeOH}$ for 4 days in the dark (MeOH changed daily). The sample was analyzed by IR (Figure 6-C) and NMR (Figure 7). Labelling estimation by determined by NMR (see Results and discussion): 15 ADIBO and 2 Fp.

\section{Results and discussion}

\subsection{Labelling of BSA with metallocarbonyl complex 2 (Scheme 1, pathway 1)}

To evaluate the feasibility of CuAAC between complex 2 and (bio)macromolecules, we first selected BSA as model protein. In a first step, some of the peripheral/accessible amino groups of lysine residues of BSA were converted to azido groups by reaction with 62 molar equiv. of the diazo transfer reagent imidazole-1-sulfonyl azide hydrochloride 4 (Figure 2). ${ }^{[44,49]}$ After purification by extensive dialysis and ultrafiltration, the IR spectrum of the modified protein $\left(\right.$ BSA-N ${ }_{3}$ ) was recorded. It showed a strong absorption band at $2102 \mathrm{~cm}^{-1}$ typical of the $\mathrm{N}=\mathrm{N}(+)=\mathrm{N}(-)$ asymmetric stretching mode, confirming the introduction of azido groups (Figure 3-A). A TNBS assay was used to measure the extent of amine modification and showed that 68 to $86 \%$ of the 35 accessible amines of BSA were converted into azides. 


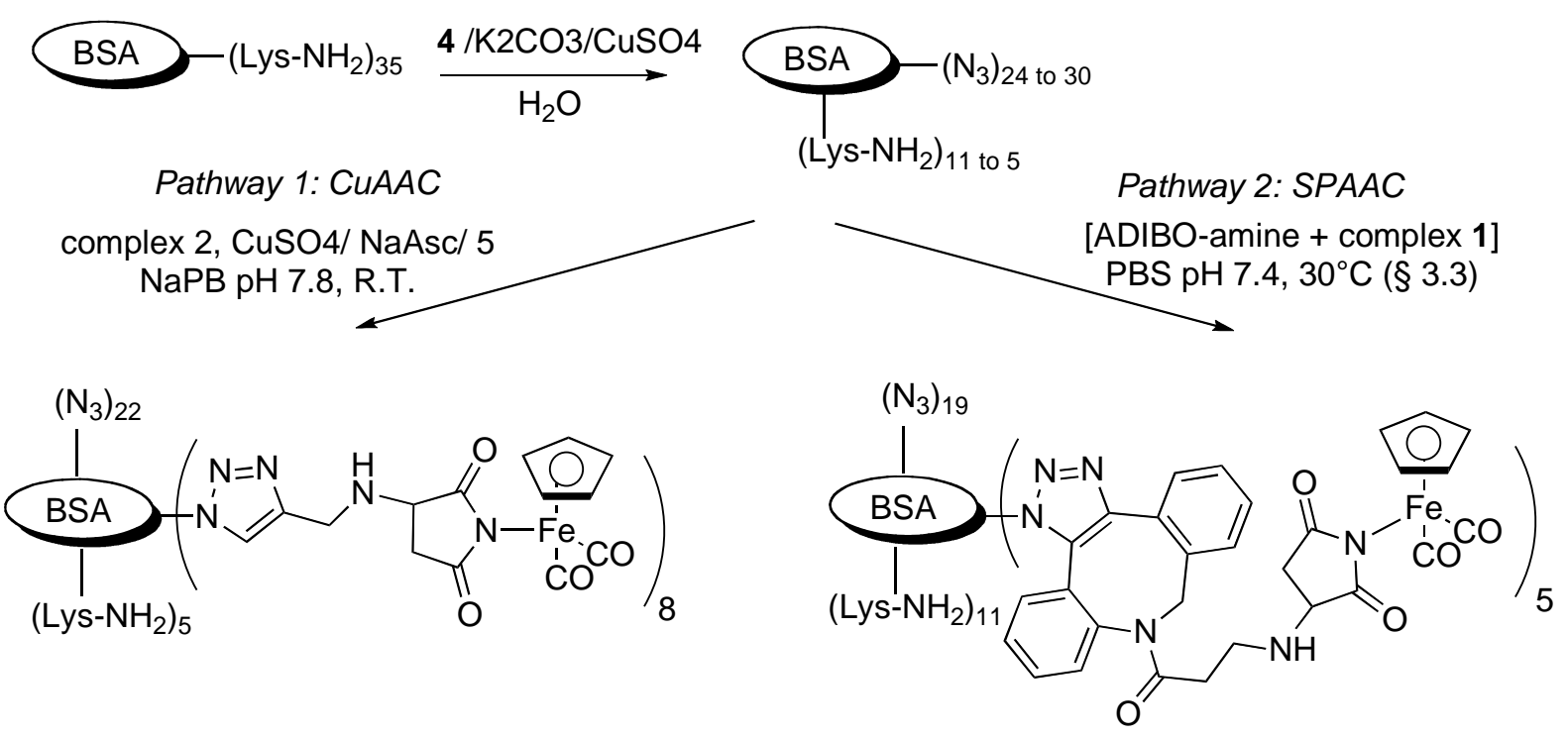

SCHEME 1 Labelling of BSA by CuAAC or SPAAC

${ }_{\mathrm{N}}^{\mathrm{HCl}} \mathrm{N}-\mathrm{SO}_{2} \mathrm{~N}_{3}$

Diazo transfer reagent 4

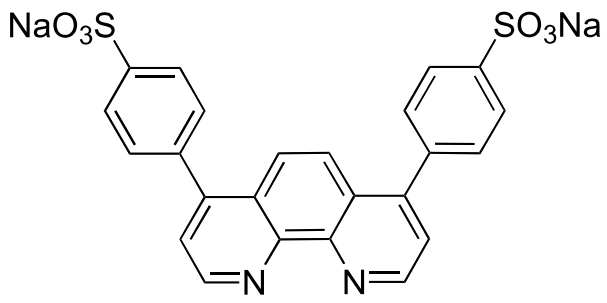

Ligand phenanthroline 5<smiles>c1ccc(Cn2nncc2CN(Cc2cnnn2Cc2ccccc2)Cc2cnnn2Cc2ccccc2)cc1</smiles>

Ligand TBTA 7

FIGURE 2 Diazo transfer reagent 4 and ligands used in the CuAAC reactions.

In a second step, BSA-N $\mathrm{N}_{3}$ (carrying 30 azido groups per protein) was treated with the terminal alkyne derivative 2 in the presence of $\mathrm{CuSO}_{4}, 4,7$-diphenyl-1,10-phenanthroline disulfonic acid disodium salt ligand 5 (Figure 2) and sodium ascorbate in sodium phosphate buffer (pH 7.8). ${ }^{[50,51]}$ The protein was purified and analysed by IR spectroscopy (Figure 3-B). The IR spectrum of the protein displayed two new absorption bands at 2052 and $2004 \mathrm{~cm}^{-1}$, readily assigned to the symmetric and asymmetric stretching modes $\left(v_{\mathrm{CO}}\right)$ of the two CO ligands of the Fp moiety, as well as a smaller band at $2106 \mathrm{~cm}^{-1}$ corresponding to unreacted azido groups. However, let us remind the relative intensities of the bands of the azido groups and the Fp entities are not to be correlated to their respective amounts since transition metallocarbonyl complexes produce intense vibrational bands that are 8 to 10 times more intense than any other band in the spectrum. We further characterized the protein conjugate 
by independently quantifying BSA by the Lowry procedure ${ }^{[46]}$ and Fp by IR analysis using a calibration curve established with standard concentrations of complex 1. A coupling ratio of 8 Fp per protein was deduced.
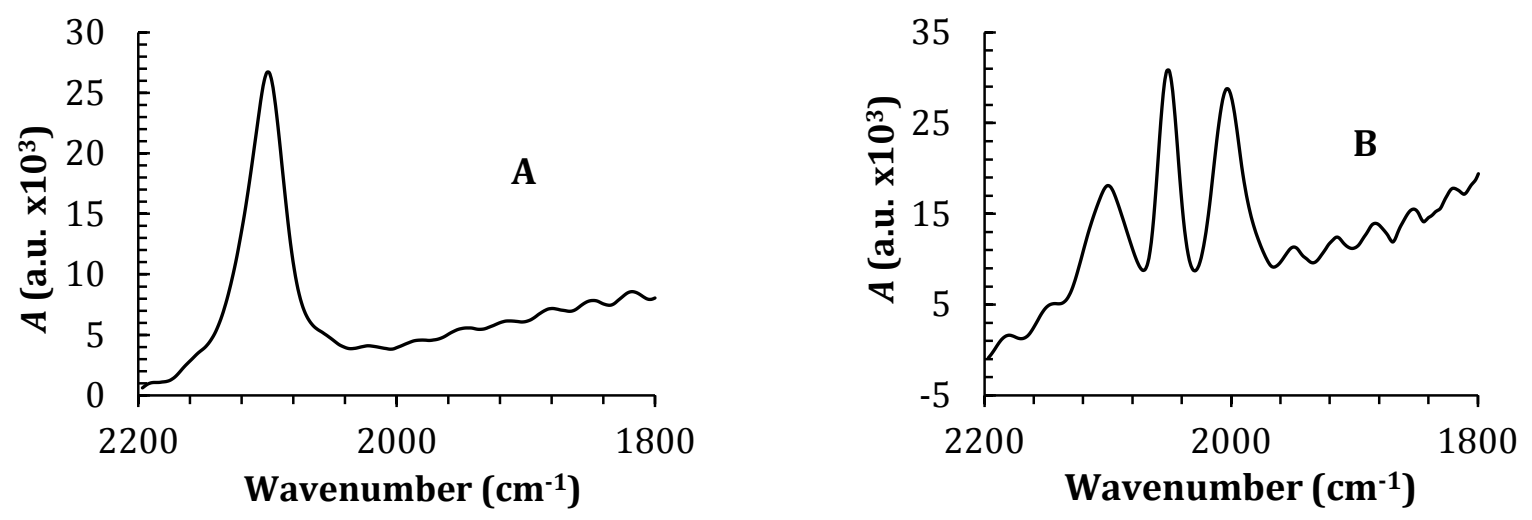

FIGURE 3 IR spectra in the $1800-2200 \mathrm{~cm}^{-1}$ range. Protein solutions in NaPB pH $7.5(4 \mu \mathrm{L})$ were deposited on nitrocellulose membranes and left to dry in air. A) BSA-N ${ }_{3}$; B) BSA-N ${ }_{3}$ labeled with Fp.

\subsection{Labelling of PAMAM-G4 with metallocarbonyl complex 2}

We next explored the labelling of PAMAM-G4 dendrimer. This biocompatible polymer displays 64 surface amino groups allowing multiple chemical modifications, thus behaving as a unique platform to design multi-functional constructs for a wide range of applications in the biomedical area (diagnosis and drug delivery, biosensors ....). ${ }^{[52-56]}$

We have previously reported the multi-labelling of PAMAM-G4 dendrimer with complex $\mathbf{1}$ by aza-Michael addition of some of its peripheral amino groups to the double bond of the maleimidato ligand of $\mathbf{1}$. We also developed two strategies to site-selectively conjugate these modified dendrimers to an antibody in order to develop new detection reagents for immunoassays. ${ }^{[41,57,58]}$ This time we investigated the reaction of azido-modified PAMAM-G4 with complex 2 by CuAAC. First, partial conversion of peripheral amine groups into azido groups was performed by reaction with 45 molar equiv. of diazo transfer reagent 4 in methanol according to a reported procedure (Scheme 2, pathway 1). ${ }^{[59]}$ The modified dendrimer 6 was analyzed by IR and MALDI-TOF mass spectrometry. The IR spectrum displayed a strong absorption band at $2104 \mathrm{~cm}^{-1}$ characteristic of the azido moiety, and the observed increase of mass $\Delta \mathrm{m}$ between commercial PAMAM-G4 and $\mathbf{6}$ in the MALDI-TOF 
MS was equal to 730, corresponding to the substitution of 28 terminal amines by azides on average (spectra in SI). 


\section{Pathway 1:}

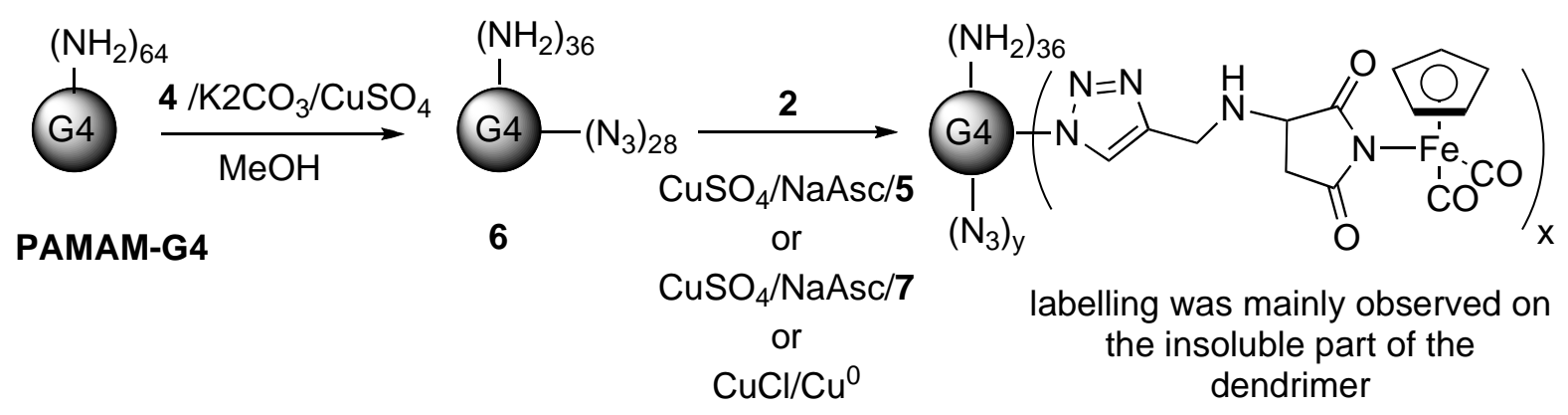

\section{Pathway 2:}
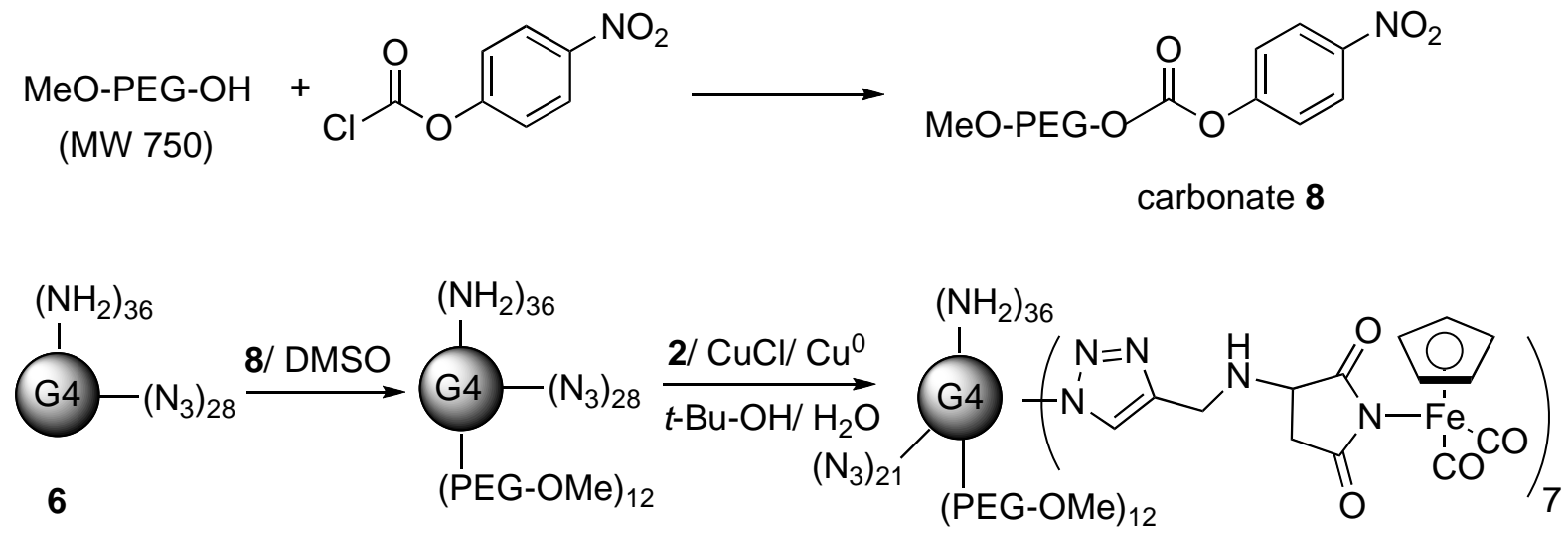

9

Pathway 3:
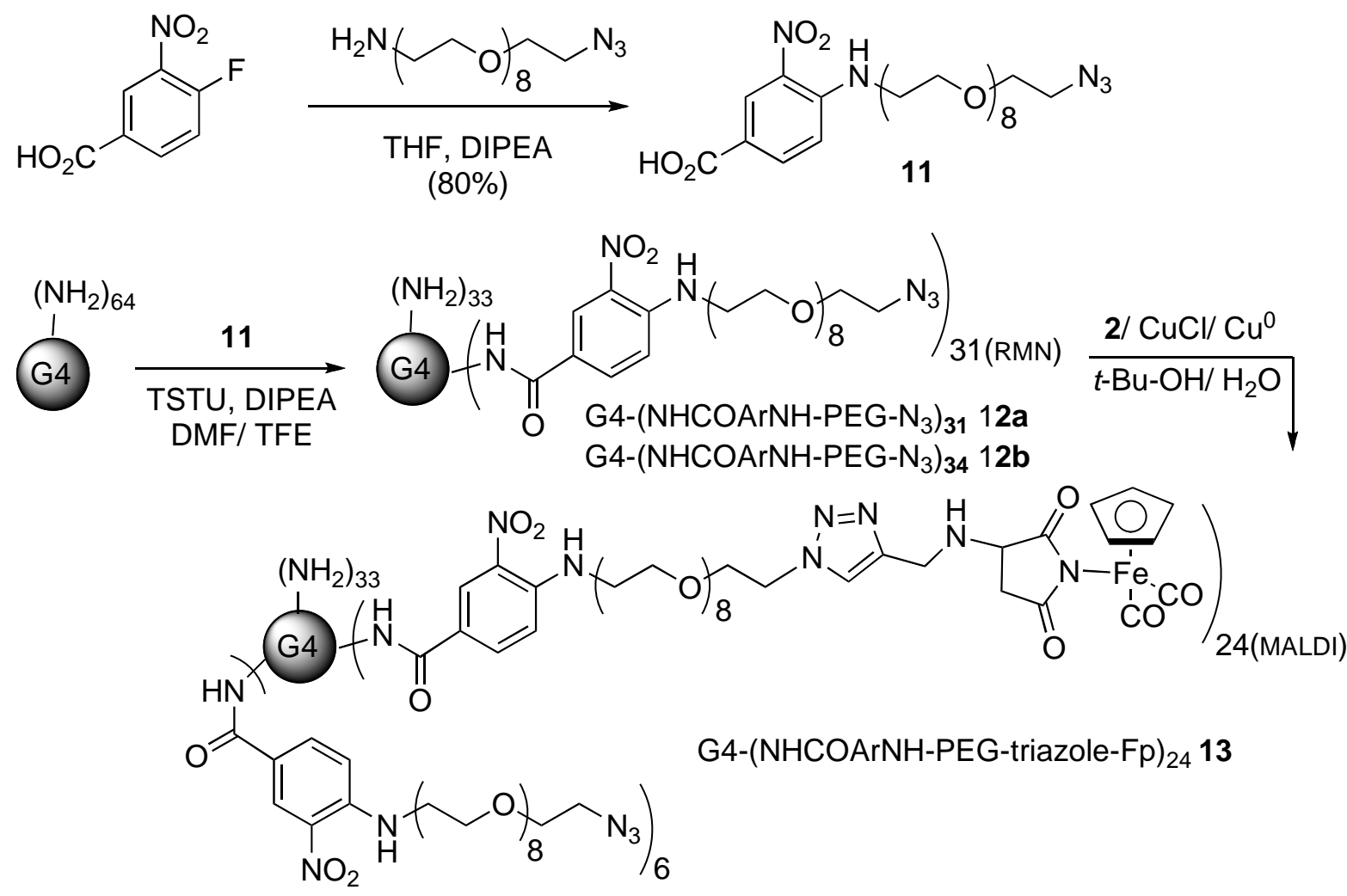

SCHEME 2 Synthetic routes to label PAMAM-G4 with complex 2. 
Reaction between alkyne complex $\mathbf{2}$ and azido dendrimer $\mathbf{6}$ was first performed in the presence of the catalytic system $\mathrm{CuSO}_{4} /$ sodium ascorbate/ phenanthroline ligand $\mathbf{5}$ according to the procedure used for labelling of BSA (Scheme 1, Pathway 1). After dialysis, a dark purple precipitate was recovered in the dialysis tubing and the supernatant was concentrated by ultrafiltration. The characteristic IR absorption bands of azide and CO ligands were only found on the ATR-IR spectrum of the precipitate (Figure 4-A) that was unfortunately insoluble in aqueous or organic media. Changing phenanthroline ligand 5 by tris[(1-benzyl1H-1,2,3-triazol-4-yl)methyl]amine (TBTA) ligand 7 (Figure 3) led again to the recovery of a precipitate in the dialysis tubing, but this time, the IR spectra of the two fractions (dried precipitate and concentrated solution) showed the three characteristic absorption bands of azide and CO ligands. Qualitatively, the fraction of soluble dendrimer was poorly labelled compared to the insoluble one (Figure 4-B and 4-C). A third catalytic system, $\mathrm{CuCl} / \mathrm{Cu}^{0}$ in $t$ $\mathrm{BuOH}-\mathrm{H}_{2} \mathrm{O}$, initially used in the $\mathrm{CuAAC}$ with aryl azides ${ }^{[39]}$ gave nearly the same results (data not shown).
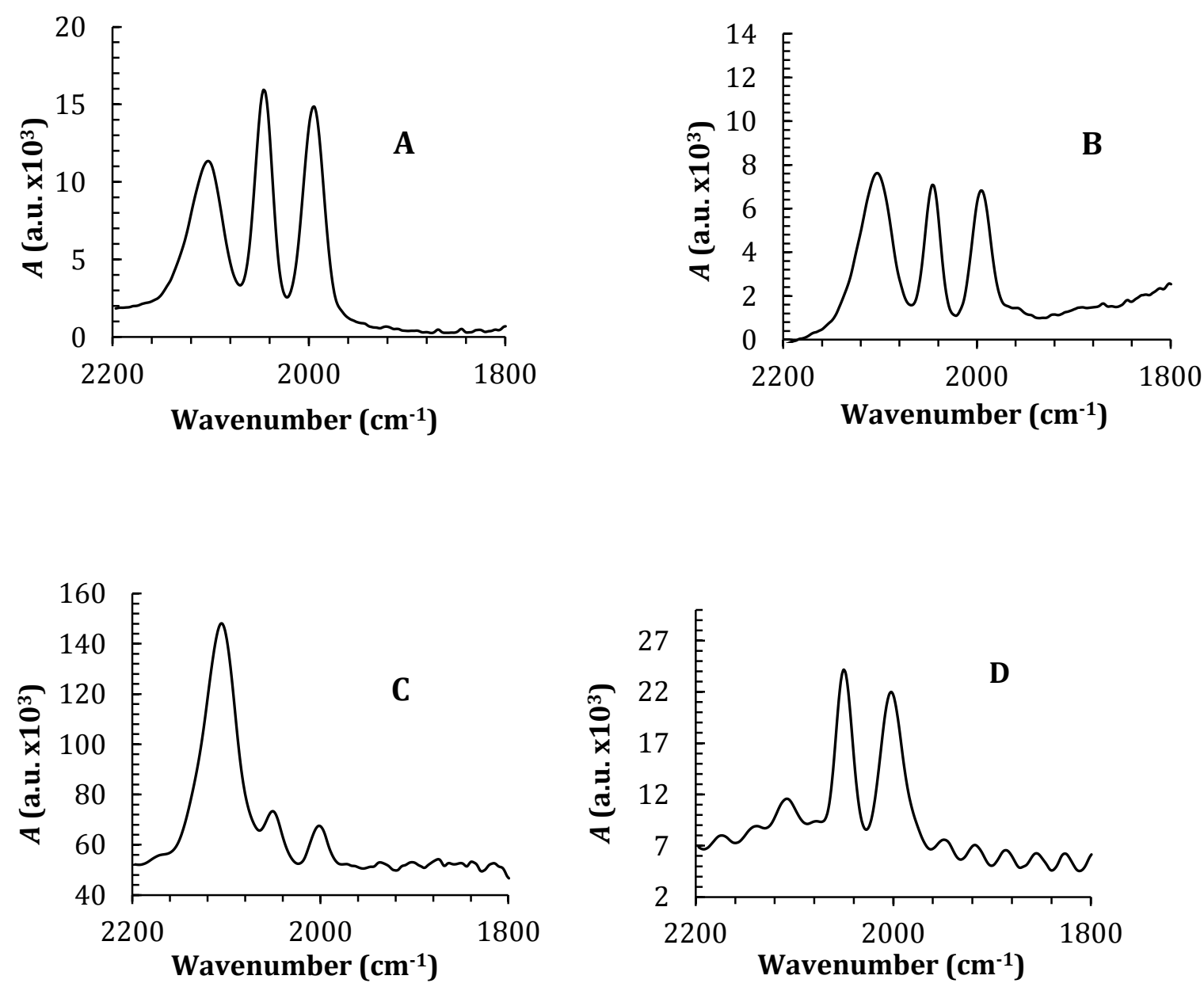

FIGURE 4 IR spectra in the $1800-2200 \mathrm{~cm}^{-1}$ range recorded in ATR mode for precipitates (A and $\mathrm{B})$ and on nitrocellulose membrane for dendrimers in solution $(\mathrm{C}$ and $\mathrm{D})$. The dendrimer 
solution ( $4 \mu \mathrm{L}$ in $\mathrm{MeOH}$ ) was left to dry and the residue was taken back in $\mathrm{H}_{2} \mathrm{O}(4 \mu \mathrm{L})$ and deposited on nitrocellulose membranes and left to dry before analysis.

These results clearly showed that multi-labelling of azido-modified PAMAM-G4 with complex 2 led to insoluble metallocarbonyl dendrimer. It was unexpected since our first generation of metallocarbonyl dendrimers prepared from Michael addition with complex 1 without any other decoration were fully soluble (in $\mathrm{MeOH}$, and in phosphate buffer) even with a high loading of $25 \mathrm{Fp}$ units on average per dendrimer. ${ }^{[58]}$

To improve the solubility, we decided to attach polyethylene glycol (PEG) chains to some of the remaining free peripheral amines of dendrimer $\mathbf{6}$ before performing $\mathrm{CuAAC}$ with $\mathbf{2}$. The terminal hydroxyl group of PEG monomethylether 750 was reacted with 4-nitrophenyl chloroformate to obtain the corresponding carbonate 8 (Scheme 2, pathway 2). ${ }^{[47]}$ ESI-MS analysis showed a Gaussian distribution of polymers in the starting material, with main peaks ranging from 12 to 19 ethylene oxide units corresponding to a mean polymer including 15 ethylene oxide units. Proton NMR showed that $70 \%$ of the polymer was converted into the corresponding carbonate (by comparing the integral of methylene group next to carbonate to integral of the terminal methoxy group). Integrals of ethylene oxide units and methoxy group were consistent with the ESI-MS estimation of 15 ethylene oxide units on average. As we intended to react an excess of MeO-PEG-carbonate with PAMAM-G4 $\left(\mathrm{N}_{3}\right)_{28}$, the presence of unactivated PEG compound was innocuous. PAMAM-G4 $\left(\mathrm{N}_{3}\right)_{28}$ and MeO-PEG-carbonate 8 were reacted in DMSO for 4 days and purified by extensive dialysis in water to remove unreacted PEG compound (Scheme 2, pathway 2). MALDI-TOF MS analysis of 9 (see SI) showed a mass increase of 9300 with respect to dendrimer 6 corresponding to the grafting of 12 PEG units on average using the average molecular mass previously estimated by ESI-MS and ${ }^{1} \mathrm{H}$ NMR.

CuAAC between PAMAM-G4(N $\left.\mathrm{N}_{3}\right)_{28}(\mathrm{PEG})_{12} 9$ and complex 2 was then carried out in $t$ $\mathrm{BuOH} / \mathrm{H}_{2} \mathrm{O}$ with $\mathrm{CuCl} / \mathrm{Cu}^{0}$ as catalyst. ${ }^{[39]}$ Purification of dendrimer $\mathbf{1 0}$ was done by dialysis in $\mathrm{MeOH} / \mathrm{H}_{2} \mathrm{O}$ to remove unreacted 2 then in $\mathrm{MeOH} / \mathrm{H}_{2} \mathrm{O}$ containing $3 \mathrm{mM}$ EDTA to remove the residual copper ions by chelation then in $\mathrm{MeOH} / \mathrm{H}_{2} \mathrm{O}$ to remove EDTA and finally in $\mathrm{MeOH}$. This time, no precipitate was observed and the solution was yellow-orange, characteristic of the Fp moiety. The IR spectrum of $\mathbf{1 0}$ displayed intense signals assigned to the CO ligands of the complex, confirming labelling as well as a small band of unreacted azido groups (Figure 4-D). MALDI-TOF MS analysis (see SI) showed a mass increase of 1050 with respect to dendrimer 9. We previously reported that the weak Fe-N bond (from 
succinimidyl) is cleaved under laser irradiation during the ionization process due to the UV sensitivity of $\mathrm{CpFe}(\mathrm{CO})_{2}$-succinimidyl derivatives. ${ }^{[41,60]}$ Thus, by postulating that $\mathrm{CpFe}(\mathrm{CO})_{2}$ entities are lost during the ionization process and that only succinimidyl moieties remain tethered to the dendrimer surface, a $\Delta \mathrm{m}$ of 152 per succinimidyl moiety is expected. Consequently, the mass increase of 1050 indicated that only 7 Fp units on average were grafted per dendrimer, starting with 30 molar equiv. of complex 2 . This coupling ratio was rather disappointing in comparison with those obtained by the direct reaction of complex $\mathbf{1}$ with PAMAM-G4, for which a loading of up to 32 Fp moieties per dendrimer was reached. ${ }^{[41]}$ One possible explanation is that the presence of PEG chains caused a steric hindrance in the neighbourhood of some of the azido groups preventing the CuAAC to take place.

To circumvent this issue, we envisioned a third route where PEG chains and azido groups would be carried by the same molecule. Furthermore, to facilitate the characterization of the macromolecule, we decided to introduce the nitroaniline motif, previously used as NMR and UV/Vis probe. ${ }^{[41,57]}$ To this end, 4-fluoro-3-nitro-benzoic acid was reacted with commercial O-(2-aminoethyl)-O'-(2-azidoethyl) heptaethylene glycol to afford azido-PEG-substituted nitroaniline 11 in $80 \%$ yield (Scheme 2, pathway 3). Conjugation to PAMAM-G4 was performed by activation of the carboxylic acid function of $\mathbf{1 1}$ with TSTU followed by reaction with surface amines of the dendrimer to form stable amide linkages. After purification by dialysis in methanol, the coupling extent was estimated by ${ }^{1} \mathrm{H}$ NMR spectroscopy in methanol- $d_{4}$. First, broadening of the aromatic proton peaks at 8.60, 7.90, and $7.00 \mathrm{ppm}$ indicated that the nitroaromatic substituent was covalently bound to the dendrimer. Then, on the basis of the integration values of one of the three aromatic peaks and the 248 methylene protons next to the carbonyl groups of the dendrimer assigned at $2.36 \mathrm{ppm}$ (assuming that the dendrimer was ideally synthesized i.e. without branch defect), an average of 31 azido-PEGsubstituted nitroaniline molecules were conjugated per dendrimer (12a), starting from 50 molar equiv. of 11. A second batch of dendrimer (12b) carrying 34 Ar-PEG-N $\mathrm{N}_{3}$ moieties on average was also prepared and used in $\S 3.3$.

A ninhydrine test was performed to estimate the number of residual amines still reactive at the dendrimer surface. ${ }^{[48]}$ It appeared that only one tenth of the peripheral amines were still reactive, although around half of them had not been modified. This result confirmed the steric hindrance brought by PEG chains postulated above and showed the benefit of introducing PEG chains and azido functional groups simultaneously. Furthermore, the nitroaniline motif was used to determine indirectly the concentration of the modified dendrimer 12a by 
measuring the concentration of the chromophore by UV/Vis spectroscopy at $416 \mathrm{~nm}$ in methanol using a calibration curve constructed with 4-butylamino-3-nitrobenzoic acid that mimics the nitroaromatic derivative attached to the dendrimer as previously reported. ${ }^{[41]}$ The concentration of dendrimer 12a in methanol solution was then easily deduced from the nitroaniline-to-PAMAM-G4 ratio determined by ${ }^{1} \mathrm{H}$ NMR.

Next, CuAAC with complex 2 was carried out in $t-\mathrm{BuOH} / \mathrm{H}_{2} \mathrm{O}$ with $\mathrm{CuCl} / \mathrm{Cu}^{0}$ as catalyst for 3 days. After purification by dialysis, it turned out that dendrimer 13 required a little amount of $\mathrm{H}_{2} \mathrm{O}$ to be fully soluble in methanol. 13 was then characterized by combining IR, UV/Vis and MALDI-TOF mass spectrometry. Quantification of Fp entities was done by IR using a calibration curve established with standard concentrations of complex 1. Quantification of the nitroaniline moiety was measured by UV-Vis spectroscopy at $416 \mathrm{~nm}$ after subtraction of absorbance of Fp (calibration curve at $416 \mathrm{~nm}$ with standard concentrations of complex 1). From these two data, we deduced that $80 \%$ of the azido groups of $\mathbf{1 2}$ were converted into metallocarbonyl triazole derivatives. The mass spectral data (see SI) showed an increase of 20 840 with respect to commercial PAMAM-G4, corresponding to the attachment of $24 \mathrm{ArNH}-$ PEG-triazole-Fp units and 6 ArNH-PEG-N 3 units on average, taking into account the calculated 80/20 ratio between clicked Fp complex and ArNH-PEG-N $\mathrm{N}_{3}$ and the cleavage of the $\mathrm{Cp}-\mathrm{Fe}(\mathrm{CO})_{2}$ moiety during the ionization process. Thus, using pathway 3 with dendrimer 12, $24 \mathrm{Fp}$ entities on average out of 30-31 azide groups (depending on the technique used to analyze the dendrimer) were attached per dendrimer molecule after CuAAC. This compares favourably with pathway 2 using dendrimer 9, for which only 7 Fp entities were bound per dendrimer after $\mathrm{CuAAC}$, although both starting dendrimers $\mathbf{9}$ and 12a carry a similar number of azido groups (28 vs. 31). Additionally, compound $\mathbf{1 1}$ proved to be an attractive heterobifunctional linker with reactive carboxylic acid and azido end groups for conjugation, PEG linker to improve solubility and a nitroaniline moiety for UV/Vis and/or NMR quantification.

\subsection{Preparation of complex 3 and reaction with $B S A-N_{3}$ and PAMAM-G4-N}

To avoid the use of copper salts responsible for adverse effects on biomolecules owing to generation of reactive oxygen species ${ }^{[50,61]}$ or to the difficulty to remove copper ions entrapped within PAMAM, ${ }^{[62]}$ we then turned to the preparation of a strained alkyne derivative of Fp complex to allow a catalyst-free, strain-promoted alkyne-azide cycloaddition (SPAAC) to take place with azide-containing biomolecules. ${ }^{[17,63-65]}$ Commercially available 
azadibenzocyclooctyne-amine (ADIBO- $\left.\mathrm{NH}_{2}\right)$ was selected as starting material to prepare compound 3 by aza-Michael addition to maleimide $\mathbf{1}$ in ethanol (Scheme 3).
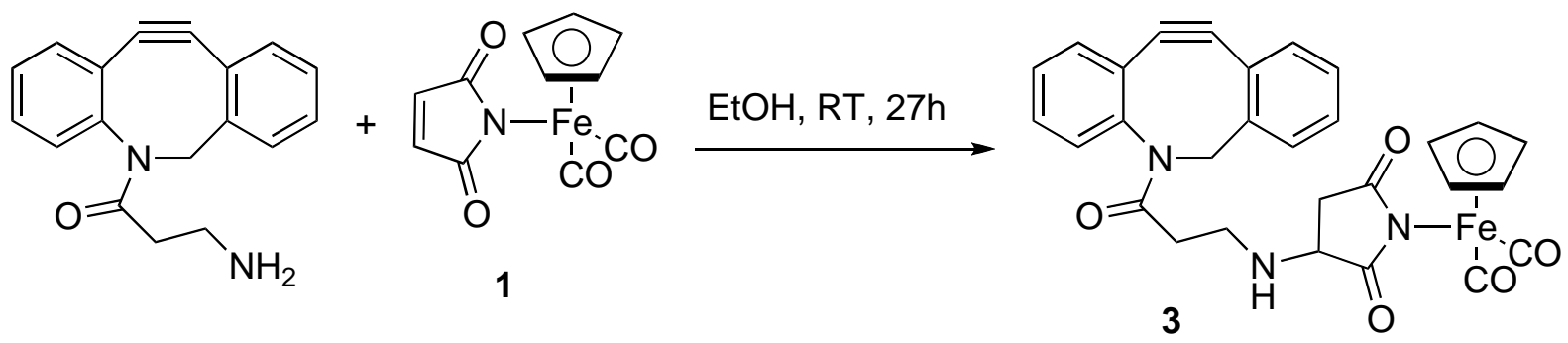

$(75 \%)$

SCHEME 3 Preparation of complex 3.

Product 3 was obtained in $75 \%$ yield. In the ${ }^{1} \mathrm{H}$ NMR, the signal corresponding to the 2 ethylenic protons of compound $\mathbf{1}$ at $6.68 \mathrm{ppm}$ was absent. Instead, the three protons of the newly formed succinimide ring gave three doublets of doublet at 2.25, 2.61 and $3.38 \mathrm{ppm}$ (Figure 5-A, blue and yellow dots). Moreover, the signal of the protons of the exocyclic methylene group in alpha of the $\mathrm{NH}$ shifted by $0.1 \mathrm{ppm}$ with respect to $\mathrm{ADIBO}-\mathrm{NH}_{2}$. The structure of compound $\mathbf{3}$ was confirmed by high resolution ESI-MS with a molecular peak at 550.1042 assigned to $[\mathrm{M}+\mathrm{H}]^{+}$. However, it turned out that this new complex was not stable in the long run, even when stored at $-20^{\circ} \mathrm{C}$, as evidenced by the ${ }^{1} \mathrm{H}$ NMR spectrum recorded after one week that showed a decrease of the $\mathrm{Cp}$ integral and signal broadening indicative of the presence of paramagnetic species due to decomplexation (Figure 5-B). This instability presumably arose from the presence in the same molecule of a reactive strained alkyne and a relatively labile $\mathrm{Fe}-\mathrm{N}$ bond. Similarly, attempts to prepare a $\mathrm{CpFe}(\mathrm{CO})_{2}$-succinimidyl derivative of bicyclo[6.1.0]nonyne (BCN) were also unsuccessful (unpublished results). 


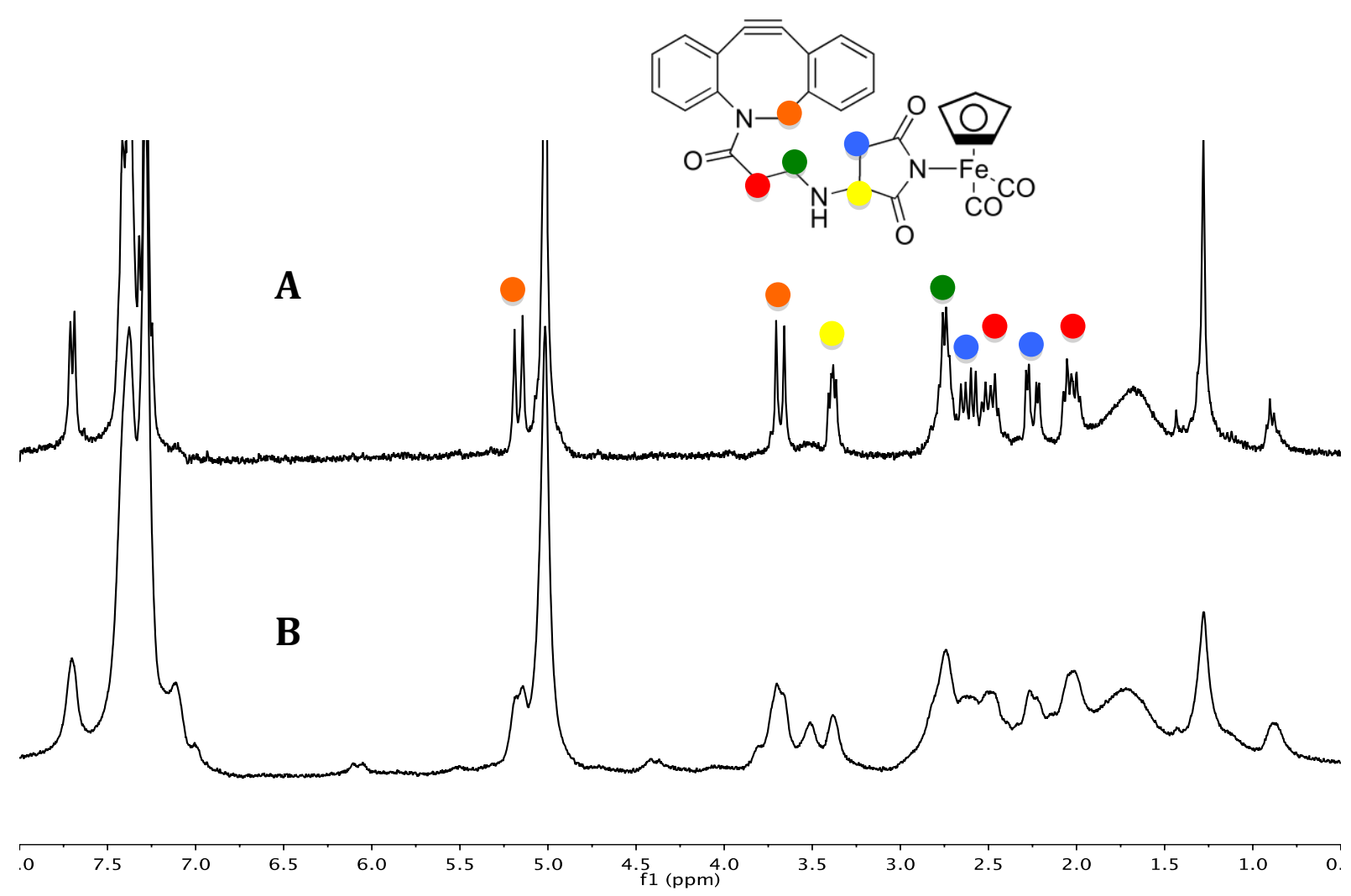

FIGURE $5{ }^{1} \mathrm{H}$ NMR spectrum of complex 3 in $\mathrm{CDCl}_{3}$, recorded immediately after purification (A) and after 1 week, storage at $-20^{\circ} \mathrm{C}(\mathrm{B})$.

Consequently, we attempted the labelling of BSA-N ${ }_{3}$ (carrying 28 azido groups per protein) following a "one-pot" procedure i.e. without purification of $\mathbf{3}$ (scheme 1, pathway 2). A stoichiometric mixture of ADIBO- $\mathrm{NH}_{2}$ and 1 (24 molar equiv. with respect to BSA-N ${ }_{3}$ ) was incubated in methanol for $24 \mathrm{~h}$ in the dark until complete disappearance of $\mathbf{1}$ as monitored by TLC. After evaporation of methanol, BSA-N $\mathrm{N}_{3}$ in PBS was added and incubated at room temperature for $24 \mathrm{~h}$. The protein was purified by dialysis and analysed by IR spectroscopy. The IR spectrum (Figure 6-A) displayed two small peaks around $2000 \mathrm{~cm}^{-1}$ and $2050 \mathrm{~cm}^{-1}$ corresponding to the Fp complex as well as an intense peak at $2100 \mathrm{~cm}^{-1}$ corresponding to unreacted azides, showing that SPAAC was not efficient in these conditions.

The SPAAC reaction between BSA-N 3 (carrying 24 azido groups per protein) and complex 3 (38 molar equiv. with respect to $\mathrm{BSA}-\mathrm{N}_{3}$ ) prepared as above was repeated at $30^{\circ} \mathrm{C}$. This time, the IR spectrum of the protein conjugate displayed only the two absorption bands of the Fp entities whereas the band at $2100 \mathrm{~cm}^{-1}$ was not visible any longer (Figure 6-B), indicating that a large proportion of the azido groups had been converted into triazoles. We further characterized the protein conjugate by independently quantifying BSA by the Lowry 
procedure and Fp by IR analysis and a coupling ratio of 5 Fp per protein was deduced. The same result was obtained with the ruthenium analogue of complex $\mathbf{3}$ (results not shown). Such a low coupling ratio was surprising since the IR spectrum displayed no more signal corresponding to azide, so that a coupling ratio closer to 28 (i.e. the number of azido groups borne by BSA in the initial protein sample) would have been expected.

To further investigate the outcome of this reaction, we applied this "one-pot" procedure to the PAMAM-G4 12b (carrying 34 Ar-PEG-N $\mathrm{N}_{3}$ moieties), which can be conveniently analysed by NMR since the chemical shifts of aromatic protons from dibenzocyclooctyne, nitroaniline and $\mathrm{Cp}$ moieties are distinct from those of the dendrimer. The cycloaddition was performed at $25^{\circ} \mathrm{C}$ and the resulting conjugate was analysed by IR and ${ }^{1} \mathrm{H}$ NMR. The IR spectrum displayed tiny absorption bands at ca. 2050 and $2000 \mathrm{~cm}^{-1}$ whereas the azide band was not visible any longer (Figure 6-C). The ${ }^{1} \mathrm{H}$ NMR of the PAMAM conjugate clearly displayed signals from the aromatic protons of the dibenzocyclooctyne, nitroaniline and Cp moieties (Figure 7). Knowing that the signal at $8.6 \mathrm{ppm}$ assigned to $\mathrm{H}-2$ from the nitroaniline ring corresponded to 34 entities, integral values in the range 7.7-7.2 ppm gave the grafting of 15 dibenzocyclooctyne units but less than $2 \mathrm{Cp}$ entities from integration of the signal at $5.2 \mathrm{ppm}$. This result clearly showed that the SPAAC did take place, explaining why we observed no more azide band on the IR spectrum of the BSA (Figure 6-B). Unfortunately, the side reaction of decomplexation of the metallocarbonyl moiety probably occurred at a similar rate as the formation of the triazole ring. These results confirmed that the $\mathrm{CpFe}(\mathrm{CO})_{2}$-succinimidyl motif is not stable in the presence of a strained alkyne.
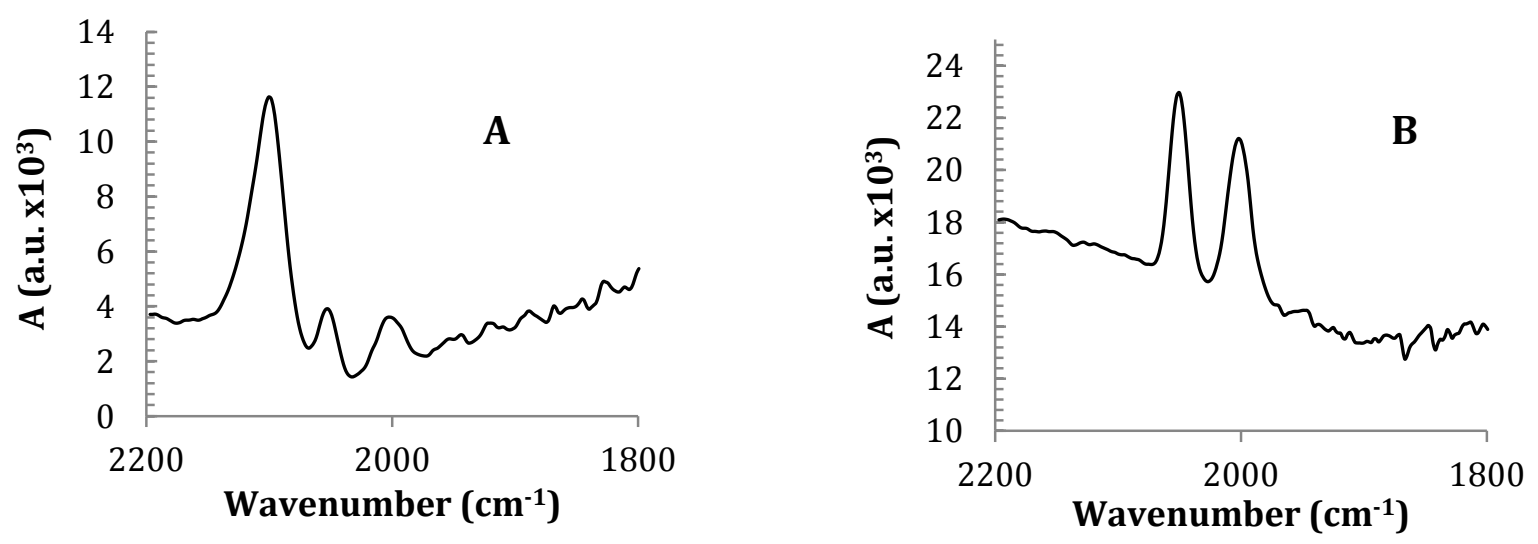


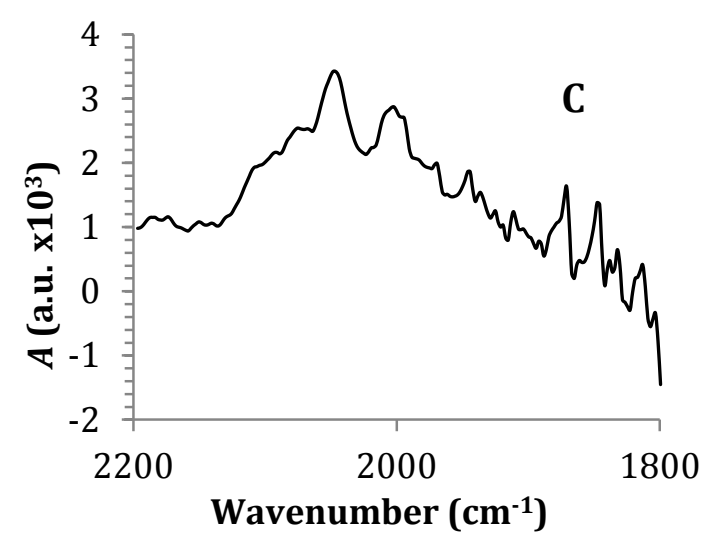

FIGURE 6 IR spectra on nitrocellulose membrane. SPAAC between BSA-N $\mathrm{N}_{3}$ and complex 3 at room temperature (A) and $30^{\circ} \mathrm{C}(\mathrm{B})$. SPAAC between PAMAM-G4(NHCO-ArNH-PEG$\left.\mathrm{N}_{3}\right)_{34} \mathbf{1 2 b}$ and complex 3 at $25^{\circ} \mathrm{C}(\mathrm{C})$.

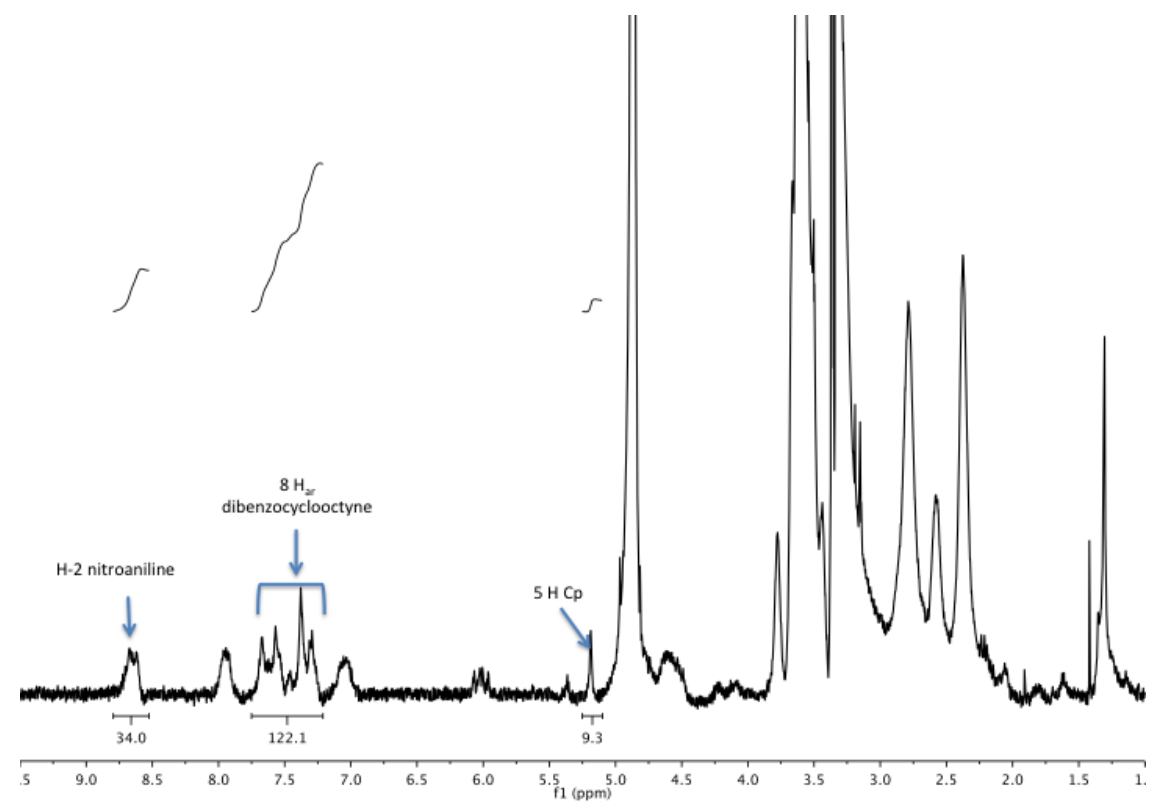

FIGURE $7{ }^{1} \mathrm{H}$ NMR spectrum of SPAAC product between PAMAM-G4(NHCO-ArNHPEG-N N $_{34}$ 12b and complex 3 (in $\mathrm{CD}_{3} \mathrm{OD}$ ). Integral value of $\mathrm{H}-2$ from nitroaniline ring was used as a standard to estimate the number of dibenzocyclooctyne and $\mathrm{CpFe}(\mathrm{CO})_{2}$ succinimidyl moieties grafted at the surface of PAMAM-G4.

\section{Conclusion}

We have introduced two alkyne-containing cyclopentadienyl iron dicarbonyl (Fp) complexes and showed that they both underwent [3+2] dipolar alkyne-azide cycloadditions with a model protein and PAMAM dendrimer generation 4 carrying azido groups. Conversion of azides and covalent coupling of Fp moieties were assessed by IR spectroscopy of the conjugates thanks 
to the stretching vibrations of the $\mathrm{C} \equiv \mathrm{O}$ and $\mathrm{N}=\mathrm{N}(+)=\mathrm{N}(-)$ bonds giving rise to intense bands in the $2000 \mathrm{~cm}^{-1}$ spectral range. Solubility issues of PAMAM conjugates were solved by introducing PEG chains from some of their peripheral amino groups. Moreover, steric hindrance brought by addition of PEG chains were circumvented by using the new heterobifunctional linker $\mathbf{1 1}$ bearing azido group at the end of the PEG chain and carboxylic acid at the other end of the linker and incorporating a nitroaniline motif for UV/Vis and/or NMR quantification. We found that the Fp moiety was fully compatible with the optimal catalysis conditions of $\mathrm{CuAAC}\left(\mathrm{CuSO}_{4}+\right.$ ascorbate + ligand $)$ reported by Finn ${ }^{[50]}$ while it appeared unexpectedly much less compatible with the conditions of SPAAC because of the intrinsic instability of strained alkyne Fp derivatives. Our next goal is now to conjugate dendrimer 13 carrying multiple copies of metal carbonyl markers to antibodies to pursue the development of new reagents for carbonyl metalloimmunoassay. Another goal would be to prepare Fp derivatives carrying a handle for another kind of non-catalysed bioorthogonal reaction such as the inverse electron demand Diels-Alder reaction with tetrazines.

\section{Acknowledgements}

This work was financially supported by the University of Lodz, Poland, Faculty of Chemistry (B. R.), CNRS and Sorbonne Université, France (N. F. D. and M. S.) and by ERASMUS + programme of the European Union for funding internships in Paris (D. L.).

\section{References}

[1] O. Boutureira, G. J. L. Bernardes Chem. Rev. 2015, 115, 2174-2195.

[2] G. T. Hermanson in Chapter 3 - The Reactions of Bioconjugation, Vol. (Ed. G. T. Hermanson), Academic Press, Boston, 2013, pp.229-258.

[3] A. D. Baldwin, K. L. Kiick Bioconjugate Chem. 2011, 22, 1946-1953.

[4] B.-Q. Shen, K. Xu, L. Liu, H. Raab, S. Bhakta, M. Kenrick, K. L. Parsons-Reponte, J.

Tien, S.-F. Yu, E. Mai, D. Li, J. Tibbitts, J. Baudys, O. M. Saad, S. J. Scales, P. J. McDonald, P. E. Hass, C. Eigenbrot, T. Nguyen, W. A. Solis, R. N. Fuji, K. M. Flagella, D. Patel, S. D. Spencer, L. A. Khawli, A. Ebens, W. L. Wong, R. Vandlen, S. Kaur, M. X. Sliwkowski, R. H. Scheller, P. Polakis, J. R. Junutula Nat. Biotechnol. 2012, 30, 184.

[5] M. F. Debets, J. C. M. van Hest, F. P. J. T. Rutjes Org. Biomol. Chem. 2013, 11, 64396455.

[6] D. M. Patterson, L. A. Nazarova, J. A. Prescher ACS Chem. Biol. 2014, 9, 592-605.

[7] H.-W. Shih, D. N. Kamber, J. A. Prescher Curr. Opin. Chem. Biol. 2014, 21, 103-111.

[8] E. M. Sletten, C. R. Bertozzi Angew. Chem. Int. Ed. 2009, 48, 6974-6998.

[9] M. Yang, J. Li, P. R. Chen Chem. Soc. Rev. 2014, 43, 6511-6526. 
[10] K. Lang, J. W. Chin Chem. Rev. 2014, 114, 4764-4806.

[11] C. S. McKay, M. G. Finn Chem. Biol. 2014, 21, 1075-1101.

[12] M. D. Best Biochemistry. 2009, 48, 6571-6584.

[13] J. Dommerholt, F. P. J. T. Rutjes, F. L. van Delft Top. Curr. Chem. (Z). 2016, 374, 16.

[14] L. Li, Z. Zhang Molecules. 2016, 21, 1393.

[15] J. C. Jewett, C. R. Bertozzi Chem. Soc. Rev. 2010, 39, 1272-1279.

[16] S. K. Mamidyala, M. G. Finn Chem. Soc. Rev. 2010, 39, 1252-1261.

[17] M. F. Debets, S. S. van Berkel, J. Dommerholt, A. J. Dirks, F. P. J. T. Rutjes, F. L. Van Delft Acc. Chem. Res. . 2011, 44, 805-815.

[18] C. J. Pickens, S. N. Johnson, M. M. Pressnall, M. A. Leon, C. J. Berkland Bioconjugate Chem. 2018, 29, 686-701.

[19] C. W. Tornoe, C. Christensen, M. Meldal J. Org. Chem. 2002, 67, 3057-3062.

[20] V. V. Rostovtsev, L. G. Green, V. V. Fokin, K. B. Sharpless Angew. Chem. Int. Ed. 2002, 41, 2596-2599.

[21] N. J. Agard, J. A. Prescher, C. R. Bertozzi J. Am. Chem. Soc. 2004, 126, 15046-15047.

[22] C. E. Anson, C. S. Creaser, J. A. Downie, O. Egyed, A. V. Malkov, L. Mojovic, G. R.

Stephenson, A. T. Turner, K. E. Wilson Bioorg. Med. Chem. Lett. 1998, 8, 3549-3554.

[23] A. Vessières, M. Salmain, P. Brossier, G. Jaouen J. Pharm. Biomed. Anal. 1999, 21, 625633.

[24] K. V. Kong, W. Chew, L. H. K. Lim, W. Y. Fan, W. K. Leong bioconjugate Chem. 2007, $18,1370-1374$.

[25] G. Santoro, T. Zlateva, A. Ruggi, L. Quaroni, F. Zobi Dalton Trans. 2015, 44, 69997008.

[26] Y. Wang, F. Heinemann, S. Top, A. Dazzi, C. Policar, L. Henry, F. Lambert, G. Jaouen, M. Salmain, A. Vessières Dalton Trans. 2018, 47, 9824-9833.

[27] R. S. Herrick, C. J. Ziegler, T. C. Leeper Journal of Organometallic Chemistry. 2014, $751,90-110$.

[28] M. Razavet, V. Artero, C. Cavazza, Y. Oudart, C. Lebrun, J. C. Fontecilla-Camps, M. Fontecave Chem. Commun. 2007, 2805-2807.

[29] J. D. Seixas, M. F. A. Santos, A. Mukhopadhyay, A. C. Coelho, P. M. Reis, L. F. Veiros, A. R. Marques, N. Penacho, A. M. L. Gonçalves, M. J. Romão, G. J. L. Bernardes, T. SantosSilva, C. C. Romão Dalton Trans. 2015, 44, 5058-5075.

[30] I. Peran, T. Oudenhoven, A. M. Woys, M. D. Watson, T. O. Zhang, I. Carrico, M. T. Zanni, D. P. Raleigh J. Phys. Chem. B. 2014, 118, 7946-7953.

[31] G. Gasser, K. Jäger, M. Zenker, R. Bergmann, J. Steinbach, H. Stephan, N. MetzlerNolte J. Inorg. Biochem. 2010, 104, 1133-1140.

[32] G. Gasser, A. M. Sosniak, A. Leonidova, H. Braband, N. Metzler-Nolte Aust. J. Chem. 2011, 64, 265-272.

[33] G. Gasser, A. Pinto, S. Neumann, A. M. Sosniak, M. Seitz, K. Merz, R. Heumann, N. Metzler-Nolte Dalton Trans. 2012, 41, 2304-2313.

[34] A. Leonidova, V. Pierroz, L. A. Adams, N. Barlow, S. Ferrari, B. Graham, G. Gasser ACS Med. Chem. Lett. 2014, 5, 809-814.

[35] A. W. T. Choi, H. W. Liu, K. K. W. Lo J. Inorg. Biochem. 2015, 148, 2-10.

[36] B. B. Kasten, X. Ma, H. Liu, T. R. Hayes, C. L. Barnes, S. Qi, K. Cheng, S. C. Bottorff, W. S. Slocumb, J. Wang, Z. Cheng, P. D. Benny Bioconjugate Chem. 2014, 25, 579-592.

[37] G. Gasser, S. Neumann, I. Ott, M. Seitz, R. Heumann, N. Metzler-Nolte Eur. J. Inorg. Chem. 2011, 5471-5478.

[38] C. Mari, S. Mosberger, N. Llorente, S. Spreckelmeyer, G. Gasser Inorg. Chem. Front. 2016, 3, 397-405.

[39] B. Rudolf Can. J. Chem. 2010, 88, 991-995. 
[40] B. Rudolf, J. Zakrzewski Tetrahedron Lett. 1994, 35, 9611-9612.

[41] N. Fischer-Durand, M. Salmain, B. Rudolf, L. Jugé, V. Guérineau, O. Laprévote, A. Vessières, G. Jaouen Macromolecules. 2007, 40, 8568-8575.

[42] M. A. van Dongen, A. Desai, B. G. Orr, J. R. Baker, M. M. Banaszak Holl Polymer. 2013, 54, 4126-4133.

[43] J. R. LLoyd, P. S. Jayasekara, K. A. Jacobson Anal. Methods. 2016, 8, 263-269.

[44] S. F. M. van Dongen, R. L. M. Teeuwen, M. Nallani, S. S. van Berkel, J. J. L. M.

Cornelissen, R. J. M. Nolte, J. C. M. van Hest Bioconjugate Chem. 2009, 20, 20-23.

[45] T. Morçöl, A. Subramanian, W. H. Velander J. Immunol. Methods. 1997, 203, 45-53.

[46] O. H. Lowry, N. J. Rosebrough, L. A. Farr, R. J. Randall J. Biol. Chem. 1951, 193, 265275.

[47] C. Kojima, K. Kono, K. Maruyama, T. Takagishi Bioconjugate Chem. 2000, 11, 910917.

[48] D. Luo, K. Haverstick, N. Belcheva, E. Han, W. M. Slatzman Macromolecules. 2002, 35, 3456-3462.

[49] E. D. Goddard-Borger, R. V. Stick Org. Lett. 2007, 9, 3797-3800.

[50] V. Hong, S. I. Presolski, C. Ma, M. G. Finn Angew. Chem. Int. Ed. 2009, 48, 9879-9883.

[51] D. P. Nguyen, H. Lusic, H. Neumann, P. B. Kapadnis, A. Deiters, J. W. Chin J. Am.

Chem. Soc. 2009, 131, 8720-8721.

[52] D. A. Tomalia, L. A. Reyna, S. Svenson Biochem. Soc. Trans. 2007, 35, 61.

[53] S. Svenson, D. A. Tomalia Adv. Drug deliv. Rev. 2012, 64, 102-115.

[54] B. Noriega-Luna, L. A. Godinez, F. J. Rodriguez, A. Rodriguez, G. Zaldivar-Lelo de Larrea, C. F. Sosa-Ferreyra, R. F. Mercado-Curiel, J. Manriquez, E. Bustos J. Nanomater. 2014, 2014, 19.

[55] S. L. Mekuria, T. A. Debele, H.-C. Tsai RSC Adv. 2016, 6, 63761-63772.

[56] E. B. Bahadir, M. K. Sezgintürk Talanta. 2016, 148, 427-438.

[57] N. Fischer-Durand, M. Salmain, B. Rudolf, L. Dai, L. Jugé, V. Guérineau, O. Laprévote, A. Vessières, G. Jaouen Anal. Biochem. 2010, 407, 211-219.

[58] N. Fischer-Durand, M. Salmain, B. Rudolf, A. Vessières, J. Zakrzewski, G. Jaouen ChemBioChem. 2004, 5, 519-525.

[59] D. K. Tosh, L. S. Yoo, M. Chinn, K. Hong, S. M. Kilbey II, M. O. Barrett, I. P. Fricks, T. K. Hraden, Z.-G. Gao, K. A. Jacobson Bioconjugate Chem. 2010, 21, 372-384.

[60] P. Haquette, M. Salmain, K. Svedlung, A. Martel, B. Rudolf, J. Zakrzewski, S. Cordier, T. Roisnel, C. Fosse, G. Jaouen ChemBioChem. 2007, 8, 224-231.

[61] S. Li, H. Cai, J. He, H. Chen, S. Lam, T. Cai, Z. Zhu, S. J. Bark, C. Cai Bioconjugate Chem. 2016, 27, 2315-2322.

[62] M. van Dijk, R. D. T. S., R. M. J. Liskamp, C. F. van Nostrum, W. E. Hennink Bioconjugate Chem. 2009, 20, 2001-2016.

[63] M. F. Debets, S. S. van Berkel, S. Schoffelen, F. P. J. T. Rutjes, J. C. M. van Hest, F. L. Van Delft Chem. Commun. 2010, 46, 97-99.

[64] J. C. Jewett, E. M. Sletten, C. R. Bertozzi J. Am. Chem. Soc. 2010, 132, 3688-3690.

[65] J. Z. Yao, C. Uttamapinant, A. Poloukhine, J. M. Baskin, J. A. Codelli, E. M. Sletten, C. R. Bertozzi, V. V. Popik, A. Y. Ting J. Am. Chem. Soc. 2012, 134, 3720-3728. 